\title{
MODIS-Satellite-Based Analysis of Long-Term Temporal-Spatial Dynamics and Drivers of Algal Blooms in a Plateau Lake Dianchi, China
}

\author{
Yuanyuan Jing ${ }^{1,2}$, Yuchao Zhang ${ }^{1,3, *}$, Minqi Hu ${ }^{1,2}$, Qiao Chu ${ }^{1,2}$ and Ronghua Ma ${ }^{1,3}$ \\ 1 Key Laboratory of Watershed Geographic Sciences, Nanjing Institute of Geography and Limnology, Chinese \\ Academy of Sciences, Nanjing 210008, China; jingyuanyuan18@mails.ucas.ac.cn (Y.J.); \\ huminqi16@mails.ucas.ac.cn (M.H.); chuqiao17@mails.ucas.ac.cn (Q.C.); rhma@niglas.ac.cn (R.M.) \\ 2 University of Chinese Academy of Sciences, Beijing 100049, China \\ 3 Jiangsu Collaborative Innovation Center of Regional Modern Agriculture \& Environmental Protection, \\ Huaiyin Normal University, Huai'an 223300, China \\ * Correspondence: yczhang@niglas.ac.cn; Tel.: +86-25-8688-2165
}

Received: 18 September 2019; Accepted: 28 October 2019; Published: 4 November 2019

\begin{abstract}
Algal blooms in eutrophic lakes have been a global issue to environmental ecology. Although great progress on prevention and control of algae have been made in many lakes, systematic research on long-term temporal-spatial dynamics and drivers of algal blooms in a plateau Lake Dianchi is so far insufficient. Therefore, the algae pixel-growing algorithm (APA) was used to accurately identify algal bloom areas at the sub-pixel level on the Moderate Resolution Imaging Spectroradiometer (MODIS) data from 2000 to 2018. The results showed that algal blooms were observed all year round, with a reduced frequency in winter-spring and an increased frequency in summer-autumn, which lasted a long time for about 310-350 days. The outbreak areas were concentrated in 20-80 km $\mathrm{km}^{2}$ and the top three largest areas were observed in 2002, 2008, and 2017, reaching $168.80 \mathrm{~km}^{2}, 126.51 \mathrm{~km}^{2}$, and $156.34 \mathrm{~km}^{2}$, respectively. After deriving the temporal-spatial distribution of algal blooms, principal component analysis (PCA) and redundancy analysis (RDA) were applied to explore the effects of meteorological, water quality and human activities. Of the variables analyzed, mean temperature $\left(\mathrm{T}_{\text {mean }}\right)$ and wind speed $(\mathrm{WS})$ were the main drivers of daily algal bloom areas and spatial distribution. The precipitation $(\mathrm{P}), \mathrm{pH}$, and water temperature (WT) had a strong positive correlation, while WS and sunshine hours (SH) had a negative correlation with monthly maximum algal bloom areas and frequency. Total nitrogen (TN) and dissolved oxygen (DO) were the main influencing factors of annual frequency, initiation, and duration of algal blooms. Also, the discharge of wastewater and the southwest and southeast monsoons may contribute to the distribution of algal blooms mainly in the north of the lake. However, different regions of the lake show substantial variations, so further zoning and quantitative joint studies of influencing factors are required to more accurately understand the true mechanisms of algae in Lake Dianchi.
\end{abstract}

Keywords: algal blooms; influencing drivers; lake dianchi; MODIS; APA

\section{Introduction}

Since ancient times, human civilization has depended on water. Lake Dianchi Basin is an area with a high population density and the highest degree of industrialization and urbanization [1], most developed economy, and most dynamic social development in Yunnan Province of China [2]. Lake Dianchi is the only water body that can receive pollutants such as urban sewage, livestock excreta, and agricultural fertilizer from the entire watershed [1,3]. With the accumulation of pollutants entering the lake, the water quality began to deteriorate gradually in the 1980s and rapidly between 1987-2000 [1]. 
Official data indicate that investment in the treatment of Lake Dianchi have reached 40-50 billion yuan (5.6-7.1 billion US dollars). The "Six Major Projects" namely, (1) lake-round interception, (2) nonpoint source control, (3) ecological restoration and construction, (4) inlet river training, (5) internal pollution control, and (6) water diversion and saving from the outer watershed $[3,4]$, have been implemented to control pollution over the last 10 years [5]. Although so many considerable efforts have been exerted by the local government and private enterprises [6], the eutrophication of the lake has not been solved effectively [7]. Algal blooms, as the sign of extreme eutrophication in aquatic systems [8], accounting for $66.44-90.66 \%$ of the total number of phytoplankton cells in Lake Dianchi [9], which still occur in different scales every year [10].

The large-scale growth of algal blooms has brought a series of ecological and environmental impacts to drinking water, cultivation, agricultural irrigation, and tourism landscape [11-14]. Among all the algal species in Lake Dianchi, Microcystis dominated can be observed from early March and last nearly 300 days yearly, which accounts for 35.69-87.97\% of phytoplankton [9,15]. A large number of Microcystis cells increase the $\mathrm{pH}$ of water bodies, lead to imbalances in the nervous system of fish [16], and represent a prominent factor responsible for inducing liver cancer [17]. Secondly, Aphanizomenon accounts for $0.46-30.75 \%$ of the total number of phytoplankton forms a small area of bloom in March [18,19], which produces an alkaloid toxin that can cause animals to die from paralysis of the respiratory muscle [20].

Based on the above-recognized information, studies on algal blooms in Lake Dianchi have gradually increased in recent years [5,17,18,21-26]. Most of these studies used fixed-point chlorophyll-a data as the response parameter for algal blooms [17,19,26-28], which has spatial and temporal discontinuities. Remote sensing data characterized by large-area simultaneous observations, strong timeliness, and dynamic continuity, are increasingly used in algal blooms monitoring and identification research [29-36]. Compared with the two other top priority lakes in China, Lake Taihu and Lake Chaohu, the remote sensing monitoring of algal blooms in Lake Dianchi has been very limited [5,22] and used mostly for short-term monitoring [25,37,38]. Zhao et al. [39] performed long-term algal blooms monitoring based on Landsat data with a $30 \mathrm{~m}$ spatial resolution from 1986 to 2016 in Lake Dianchi. Although the algal blooms' information of this study was more accurate than previous studies, the 16-day temporal resolution was insufficient to characterize rapid changes in algal blooms. Jiang [13] used Moderate Resolution Imaging Spectroradiometer (MODIS) data with an extremely high temporal resolution from 2000 to 2015 to monitor Dianchi algae, however, due to the limited spatial resolution of this study, mixed pixels were relatively common. Compared with other nonlinear identification methods such as the normalized difference vegetation index (NDVI) and enhanced vegetation index (EVI), floating algae index (FAI) is not easily affected by the aerosol thickness and observation angle, which can penetrate thin clouds more effectively. This index has been widely applied to monitor algal blooms [32,35,39-43]. Based on the low sensitivity of the FAI, the algae pixel-growing algorithm (APA) is combined to calculate the algal bloom area to sub-pixels [44]. It has been applied to Lake Taihu and Lake Chaohu, which has been proved to be more objective and accurate in real-time monitoring and historical analysis [30,45,46].

This study, therefore, aims to explore the temporal-spatial distribution of algal blooms in Lake Dianchi from 2000 to 2018 more precisely by APA on MODIS. After analyzing the effects of meteorological, water quality, and human activities on algal blooms at different time scales, we recognize the major influencing factors and quantify their impacts. The results of this study may provide a theoretical basis of the eutrophication of Lake Dianchi, and offer some valuable information on algal blooms prediction and corresponding mitigation and control methods for other lakes. 


\section{Data and Methods}

\subsection{Study Site}

Lake Dianchi $\left(102^{\circ} 29^{\prime} 9^{\prime \prime}-103^{\circ} 0^{\prime} 51^{\prime \prime} \mathrm{E}, 24^{\circ} 28^{\prime} 10^{\prime \prime}-25^{\circ} 27^{\prime} 24^{\prime \prime} \mathrm{N}\right)$ is located in the southwest of Kunming City, the capital of Yunnan Province in southwest China. It extends $39.4 \mathrm{~km}$ from north to south and $12.66 \mathrm{~km}$ from west to east and is slightly arched back to the east (Figure 1). The lake covers an area approximately $310 \mathrm{~km}^{2}$ with an average depth of $4.9 \mathrm{~m} \mathrm{[3],} \mathrm{which} \mathrm{is} \mathrm{the} \mathrm{largest} \mathrm{lake} \mathrm{in} \mathrm{the}$ Yunnan-Guizhou Plateau and used to be called the "pearl of the highland" because of its picturesque scenery [47]. Lake Dianchi has been divided into two parts by the Xiyuan Tunnel since 1996: Caohai (north, 2.5\% of the entire lake) and Waihai (middle and south, $97.5 \%$ of the entire lake) [48].
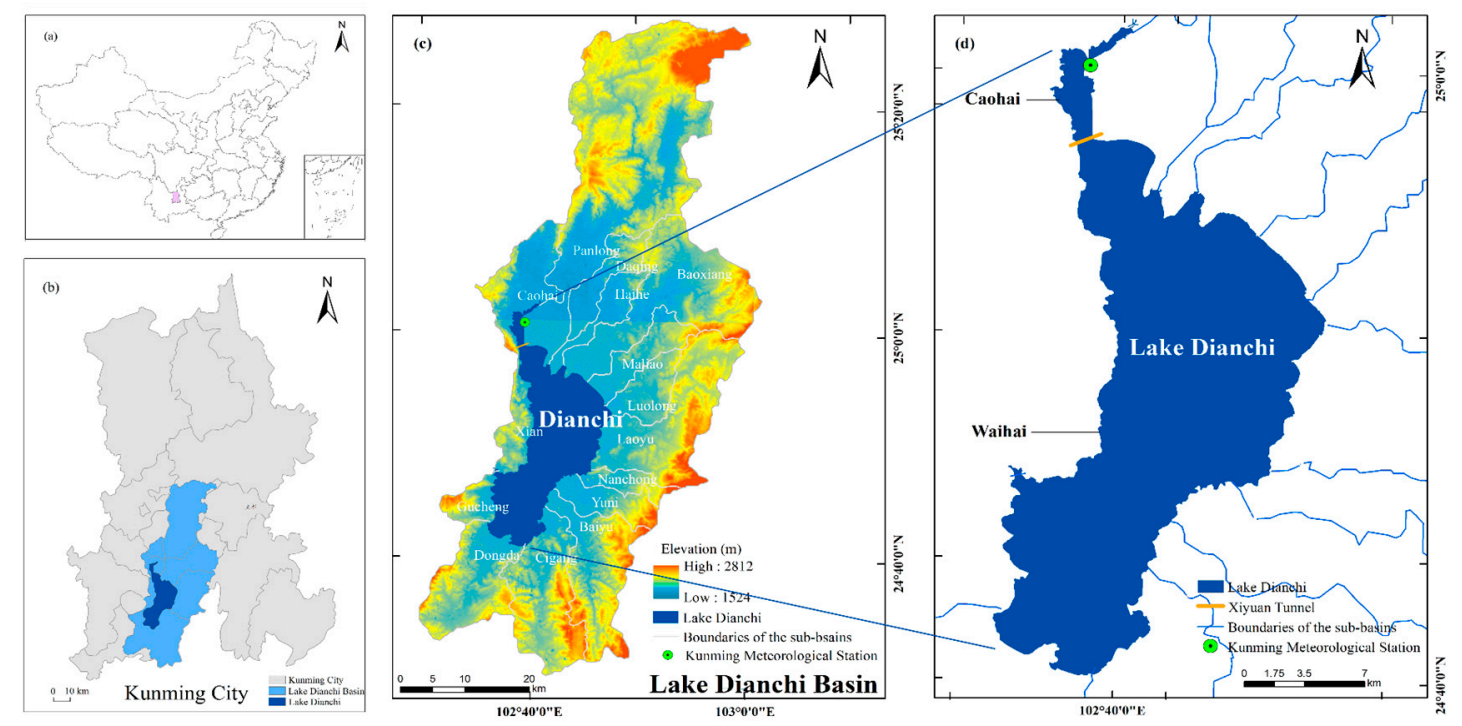

Figure 1. Location of Lake Dianchi, China. (a) Location of Lake Dianchi Basin in China; (b) distribution of the water body and Lake Dianchi Basin in Kunming City; (c) distribution of the water body in the basin; and (d) Lake Dianchi.

The water of Lake Dianchi is completely mixed and does not freeze during the year due to the monsoon climate and wind disturbances in the subtropical plateau [1], which create natural conditions that promote occurring algae. Also, developed economy, dense population, high-level urbanization, and serious water quality problems of Lake Dianchi Basin create favorable social conditions for algal blooms [3]. Under the combined effects of various factors, the algal blooms explode different degrees every year.

\subsection{Satellite and Other Data}

\subsubsection{Satellite Data Acquisition and Pre-Processing}

A total of 1309 of at least 75\% cloud-free MODIS Level-0 data (Terra and Aqua) covering the years 2000-2018 over Lake Dianchi were collected from the NASA EOS Data Gateway (EDG). Then, the calibrated radiance data (Level-1B) were obtained by SeaDAS (version 7.2). The data were georeferenced to the Universal Transverse Mercator (UTM) projection with an error of fewer than 0.5 pixels. The ground $500 \mathrm{~m}$ resolution of the MODIS data $(1240 \mathrm{~nm})$ was resampled to $250 \mathrm{~m}$ resolution to match the resolution at $645 \mathrm{~nm}$ by using the nearest neighbor method in ENVI (version 5.3). The Rayleigh-corrected reflectance ( $R_{r c}$, dimensionless) was derived after the Level-1B data were corrected for gaseous absorption (mainly by ozone) and Rayleigh (molecular) scattering effects using the routines and look up tables (LUTs) available in SeaDAS (version 7.2) [45]. 
Six quasi-synchronized cloudless Landsat TM/ETM+ Level-1 images (09/15/2000, 11/02/2000, 10/07/2002, 04/06/2005, 08/04/2005, and 08/15/2006) of Lake Dianchi in the presence of algae were downloaded from the Earth Resources Observation and Science (EROS) Center (http://glovis.usgs.gov). The geometric correction was applied to these images using a 1:50000 topographic map within an error of fewer than 0.5 pixels. Subsequently, these images were processed by the same atmospheric correction to get $R_{r c}$, which followed the calculation requirements and steps strictly of the floating algae index (FAI) by Hu et al. [40,49].

\subsubsection{Other Data}

Meteorological, water quality, and human activities data of Lake Dianchi were collected and analyzed in this study [3,50-53]. Meteorological data include the daily mean air temperature $\left(\mathrm{T}_{\text {mean }}\right)$, maximum air temperature $\left(T_{\max }\right)$, minimum air temperature $\left(T_{\min }\right)$, wind speed (WS), wind direction (WD), sunshine hours ( $\mathrm{SH}$, the duration from sunrise to sundown, minus the cloudy hours), and 20-20 $\mathrm{h}$ precipitation ( $\mathrm{P}$, the amount of precipitation from 20:00 on one day to 20:00 on the next day) of the Lake Dianchi Basin from 2000 to 2018. These data were obtained from the Kunming Meteorological Station (station no. $56778,25^{\circ} \mathrm{N}, 102^{\circ} 23^{\prime} 24^{\prime \prime} \mathrm{E}, 1888.1 \mathrm{~m}$ altitude) on the website of the China Meteorological Data Service Center (CMDC) (http://data.cma.cn/en).

The water quality data mainly include the yearly and monthly mean $\mathrm{pH}$, total nitrogen (TN), total phosphorus (TP), nitrogen-phosphorus ratio (TN/TP), dissolved oxygen (DO), chemical oxygen demand $\left(\mathrm{COD}_{\mathrm{Mn}}\right)$, ammonia-nitrogen $\left(\mathrm{NH}_{3}-\mathrm{N}\right)$, and water temperature $(\mathrm{WT})$. TN, TP, and TN/TP data for 2000-2015 and WT for 2005-2015 were obtained from published literature [5,54]. The weekly average $\mathrm{pH}, \mathrm{DO}, \mathrm{COD}_{\mathrm{Mn}}$, and $\mathrm{NH}_{3}-\mathrm{N}$ values from 2006 to 2018 were obtained from the China National Environmental Monitoring Centre (CNEMC) (http://www.cnemc.cn/).

The monthly values were obtained by averaging the data of all the corresponding days in each given month, and the annual values were obtained by averaging all the monthly values in each particular year. Monthly meteorological and water quality changes were analyzed through average data sets for specific months from 2000 to 2018.

The socioeconomic data, including Kunming City's total population (TPop), gross domestic product (GDP), and total wastewater discharge (TW), were downloaded from the Yunnan Statistical Yearbook (YSY) (www.stats.yn.gov.cn). Table 1 shows the specific parameters of the influencing factors.

Table 1. Influencing factors used in this study.

\begin{tabular}{|c|c|c|c|c|c|c|}
\hline Category & Parameter & Abb. ${ }^{a}$ & Unit & $\begin{array}{c}\text { Available } \\
\text { Time Span }\end{array}$ & Data Type & Data Source \\
\hline \multirow{7}{*}{$\begin{array}{l}\text { Meteorological } \\
\text { factors }\end{array}$} & Mean air temperature & $\mathrm{T}_{\text {mean }}$ & ${ }^{\circ} \mathrm{C}$ & \multirow{7}{*}{ 2000-2018 } & \multirow{7}{*}{$\begin{array}{c}\text { Daily; } \\
\text { monthly; } \\
\text { yearly }\end{array}$} & \multirow{7}{*}{$\mathrm{CMDC}^{\mathrm{b}}$} \\
\hline & Maximum air temperature & $\mathrm{T}_{\max }$ & ${ }^{\circ} \mathrm{C}$ & & & \\
\hline & Minimum air temperature & $\mathrm{T}_{\min }$ & ${ }^{\circ} \mathrm{C}$ & & & \\
\hline & Wind speed & WS & $\mathrm{m} / \mathrm{s}$ & & & \\
\hline & Wind direction & WD & - & & & \\
\hline & Sunshine hours & $\mathrm{SH}$ & $\mathrm{H}$ & & & \\
\hline & 20-20 h Precipitation & $\mathrm{P}$ & $\mathrm{mm}$ & & & \\
\hline \multirow{8}{*}{$\begin{array}{l}\text { Water quality } \\
\text { factors }\end{array}$} & Total nitrogen & $\mathrm{TN}$ & $\mathrm{mg} / \mathrm{L}$ & & & \\
\hline & Total phosphorus & $\mathrm{TP}$ & $\mathrm{mg} / \mathrm{L}$ & 2000-2015 & Monthly; & $\begin{array}{l}\text { Guo et al., 2017; } \\
\text { Wang et al. 2019 [5;55] }\end{array}$ \\
\hline & Nitrogen-phosphorus ratio & $\mathrm{TN} / \mathrm{TP}$ & - & & & \\
\hline & $\mathrm{pH}$ & $\mathrm{pH}$ & - & \multirow{4}{*}{ 2006-2018 } & \multirow{4}{*}{$\begin{array}{l}\text { Weekly; } \\
\text { monthly; } \\
\text { yearly }\end{array}$} & \multirow{4}{*}{$\mathrm{CNEMC}^{\mathrm{c}}$} \\
\hline & Dissolved oxygen & DO & $\mathrm{mg} / \mathrm{L}$ & & & \\
\hline & Chemical oxygen demand & $\mathrm{COD}_{\mathrm{Mn}}$ & $\mathrm{mg} / \mathrm{L}$ & & & \\
\hline & Ammonia-nitrogen & $\mathrm{NH}_{3}-\mathrm{N}$ & $\mathrm{mg} / \mathrm{L}$ & & & \\
\hline & Water temperature & WT & ${ }^{\circ} \mathrm{C}$ & 2005-2015 & $\begin{array}{l}\text { Monthly; } \\
\text { yearly }\end{array}$ & Wang et al., 2019 [5] \\
\hline \multirow{3}{*}{$\begin{array}{l}\text { Socioeconomic } \\
\text { factors }\end{array}$} & Total population & TPop & $10^{4}$ persons & \multirow{3}{*}{ 2000-2017 } & \multirow{3}{*}{ Yearly } & \multirow{3}{*}{$Y_{S Y}^{d}$} \\
\hline & Gross domestic product & GDP & $10^{10} \mathrm{CNY}$ & & & \\
\hline & Total wastewater discharge & TW & $10^{7}$ tons & & & \\
\hline
\end{tabular}

Notes: ${ }^{\mathrm{a}} \mathrm{Abb} .=$ Abbreviation, ${ }^{\mathrm{b}} \mathrm{CMDC}=$ China Meteorological Data Service Center,${ }^{\mathrm{c}} \mathrm{CNEMC}=\mathrm{China}$ National

Environmental Monitoring Centre, ${ }^{\mathrm{d}}$ YSY = Yunnan Statistical Yearbook. 


\subsection{Algal Bloom Area Calculation Methods}

\subsubsection{FAI Algorithm}

Under the MODIS band setting, the greatest difference between algal-bloom and non-algal-bloom areas of a water body occurs when the $645 \mathrm{~nm}$ and $1240 \mathrm{~nm}$ bands are used as the base point of both ends, and the $859 \mathrm{~nm}$ band is the central wavelength. Based on this feature, the FAI $[40,41]$ was calculated as:

$$
\begin{gathered}
F A I=R_{r c, N I R}-R_{r c, N I R}^{\prime} \\
R_{r c, N I R}^{\prime}=R_{r c, R E D}+\left(R_{r c, S W I R}-R_{r c, R E D}\right) \times\left(\lambda_{N I R}-\lambda_{R E D}\right) /\left(\lambda_{S W I R}-\lambda_{R E D}\right)
\end{gathered}
$$

where $R_{r c, R E D}, R_{r c, N I R}$, and $R_{r c, S W I R}$ represent the red, near-infrared, and short-wave infrared reflectances, respectively, after Rayleigh scattering is removed. $\lambda_{R E D}, \lambda_{N I R}$, and $\lambda_{S W I R}$ indicate the corresponding wavelengths of MODIS $\left(\lambda_{R E D}=645 \mathrm{~nm}, \lambda_{N I R}=859 \mathrm{~nm}\right.$, and $\left.\lambda_{S W I R}=1240 \mathrm{~nm}\right) . R_{r c, N I R}^{\prime}$ is the baseline reflectance of the $890 \mathrm{~nm}$ band based on the linear interpolation of the $645 \mathrm{~nm}$ and $1240 \mathrm{~nm}$ bands.

\subsubsection{Thresholds of Pure-Algae and None-Algae Pixels}

The high difference between algae and none-algae areas of water bodies leads to sharp changes, with a large gradient among the pixels. After the FAI values of MODIS images were generated automatically, according to the sum of FAI difference between each pixel and its adjacent three by three pixels on the boundary, the gradient distribution histogram was drawn to determine the algal threshold of each image. Then subtracted twice the standard deviation from the average threshold of FAI of all 1309 images, the threshold of none-algae pixels was defined as -0.004 . Assuming that the algal blooms in the Landsat TM/ETM+ images were pure, we mapped them to synchronous MODIS images and obtained the FAI distribution of pure algae. The threshold of the pure-algae pixels was determined to be 0.05 after minus the standard deviation from the average FAI [44].

\subsubsection{Calculation of Algal Coverage of Mixed Pixels via APA}

We defined algal coverage $(\alpha)$ as the proportion of mixed pixels covered by algae and divided the MODIS image pixels of Lake Dianchi into three categories: Pure-algae $(\alpha=100 \%)$, none-algae $(\alpha=0)$, and mixed pixels [44-46].

The APA [44] was based on pure pixels of the FAI and the computations of two hypotheses:

Hypothesis 1: In every three by three pixel window, the FAI value of the center pixel can be utilized as a linear combination of the maximum and minimum FAI values of the eight surrounding pixels:

$$
F A I_{\text {center }}=\gamma F A I_{\max }+(1-\gamma) F A I_{\min }
$$

where $\gamma$ is the decomposition coefficient in the three by three pixel, determined based on the linear relationship between known FAI values $\left(F A I_{\text {center }}, F A I_{\max }\right.$, and $\left.F A I_{\min }\right)$.

Hypothesis 2: The FAI of any mixed pixel can be decomposed into a linear combination of the pure-algae and none-algae pixels:

$$
\begin{aligned}
& F A I_{\text {mixed }}=\alpha F A I_{\text {algae }}^{\text {thresh }}+(1-\alpha) F A I_{\text {none-algae }}^{\text {thresh }} \\
& =\left(F A I_{\text {algae }}^{\text {thresh }}-F A I_{\text {none-algae }}^{\text {thresh }}\right) \alpha+F A I_{\text {none-algae }}^{\text {thresh }}
\end{aligned}
$$


where $F A I_{\text {algae }}^{\text {thresh }}$ and $F A I_{\text {none-algae }}^{\text {thres }}$ represent the FAI thresholds of pure-algae and none-algae pixels, respectively, and $\alpha$ is the algal coverage of the mixed pixels. The following can be obtained based on Formula (4):

$$
F A I=m \alpha+k
$$

where $m$ and $k$ are constants $\left(m=F A I_{\text {algae }}^{\text {thresh }}-F A I_{\text {none-algae }}^{\text {thresh }}, k=F A I_{\text {none-algae }}^{\text {threh }}\right) . F A I_{\text {min }}=m \alpha_{\text {min }}+k$ and $F A I_{\max }=m \alpha_{\max }+k$ are substituted into Formula (5),

$$
m \alpha_{\text {center }}+k=\gamma\left(m \alpha_{\max }+k\right)+(1-\gamma)\left(m \alpha_{\min }+k\right)
$$

that is:

$$
\alpha_{\text {center }}=\gamma \alpha_{\max }+(1-\gamma) \alpha_{\text {min }}
$$

where $\alpha_{\max }$ and $\alpha_{\min }$ are the algae coverages of pixels with maximum and minimum FAI values in a three by three window, respectively. When $\alpha$ is not zero, the algal bloom areas in the pixels is 0.25 by 0.25 by $\alpha$. Then, the algal area of the entire lake can be calculated by $0.25 \times 0.25 \times \sum_{1}^{i} \alpha_{i}$ (where $i$ is the number of pixels).

\subsection{Temporal-Spatial Characteristic Determination}

We identified the spatial distribution of bloom frequency and the annual initiation date and duration to describe the dynamic characteristics of algal blooms.

Based on further classification (year and month), the monthly and annual frequencies of the algal bloom of each pixel were calculated as:

$$
F_{i, j}=\frac{C_{i, j}}{T C_{j}}
$$

where $F_{i, j}$ is the bloom frequency of pixel $i$ over $j$ days, $C_{i, j}$ is the bloom occurrence count, and $T C_{j}$ is the total count of MODIS images.

Based on the cyclic changes in annual temperature and precipitation (Figure 2) of Lake Dianchi Basin for 2012-2016, the period of this study was determined to be from January 1 to December 31 of the same year. Algal bloom initiation was defined as the first moment after January 1 that the algal bloom coverage value was greater than $5 \%\left(15 \mathrm{~km}^{2}\right)$ of the entire lake. Furthermore, we defined bloom duration as the number of days between the initiation and last date that the algal bloom area was $15 \mathrm{~km}^{2}$. For the entire lake, the significant algal bloom initiation and final date were defined as the first and last moments in the lake district when $>10 \%\left(30 \mathrm{~km}^{2}\right)$ of the pixels showed none-zero algal bloom coverage. Initiation dates were transformed into a Julian date format [45].

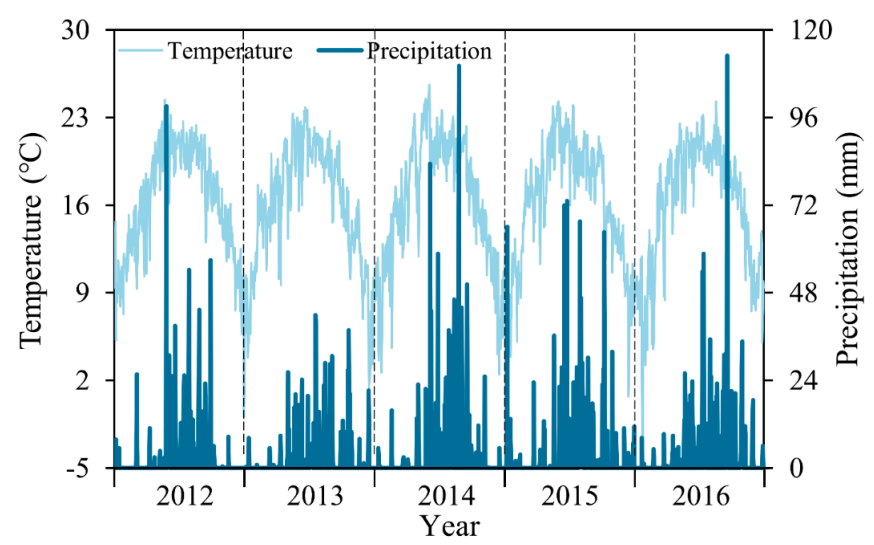

Figure 2. Air temperature and precipitation changes of Lake Dianchi for 2012-2016. 


\subsection{Statistical Methods}

In this study, the validation of the APA and the spatial-temporal distribution and drivers of the long-time sequence of algal blooms in Lake Dianchi were determined by several multivariate statistical methods. Table 2 lists these methods in detail.

Table 2. Statistical methods for determining the spatial-temporal distribution and environmental drivers of the long-term sequence of algal blooms in Lake Dianchi.

\begin{tabular}{ccc}
\hline Method & Content & Software \\
\hline $\begin{array}{c}\text { Root mean square error (RMSE) } \\
\text { Relative error (RE) }\end{array}$ & Validation of the APA & Excel \\
\hline Ward's minimum variance & & \\
Hot spot analysis & Temporal-spatial distributions of & RStudio \\
Trajectory data mining & pixel-bloom frequency & ArcGIS \\
\hline $\begin{array}{c}\text { principal component analysis (PCA) } \\
\text { redundancy analysis (RDA) }\end{array}$ & $\begin{array}{c}\text { Influencing drivers of algal } \\
\text { blooms at daily, monthly, and } \\
\text { inter-annual scales }\end{array}$ & Canoco \\
\hline
\end{tabular}

\section{Results}

\subsection{Validation of the APA}

As a result of satellite remote sensing inversion, in situ data or higher-resolution images are usually used for verification. However, it is difficult or impossible to verify the range and area of the planar distribution of algal blooms in Lake Dianchi using fixed-point data. Therefore, this study used higher-resolution Landsat TM/ETM+ data (spatial resolution $30 \mathrm{~m}$ ) to evaluate the accuracy of the MODIS (spatial resolution $250 \mathrm{~m}$ ) algal bloom monitoring results. We assumed that there were only pure-algae and none-algae pixels existing in Landsat images, then we use FAI, which has been widely used with high precision $[13,41,43]$, to extract algal bloom areas. The spatial distributions of these six comparison images were roughly the same (Figure 3), there was a little inconsistent distribution of algal bloom area in the north of the lake in 08/04/2005, which may be related to the difference of transit time on MODIS/Aqua and Landsat. Meanwhile, it can be seen from this picture that APA did not mistake the thin cloud for algal blooms. Further quantitative analysis of the algal bloom areas indicated that both results were near the bloom contour, and the root mean square error (RMSE) was $2.27 \mathrm{~km}^{2}$, and the relative error (RE) was 5.63\% (Figure 4). Given the small error, the APA was deemed accurate, reliable, and able to provide data support for the scientific decision-making of relevant management departments in Lake Dianchi. 

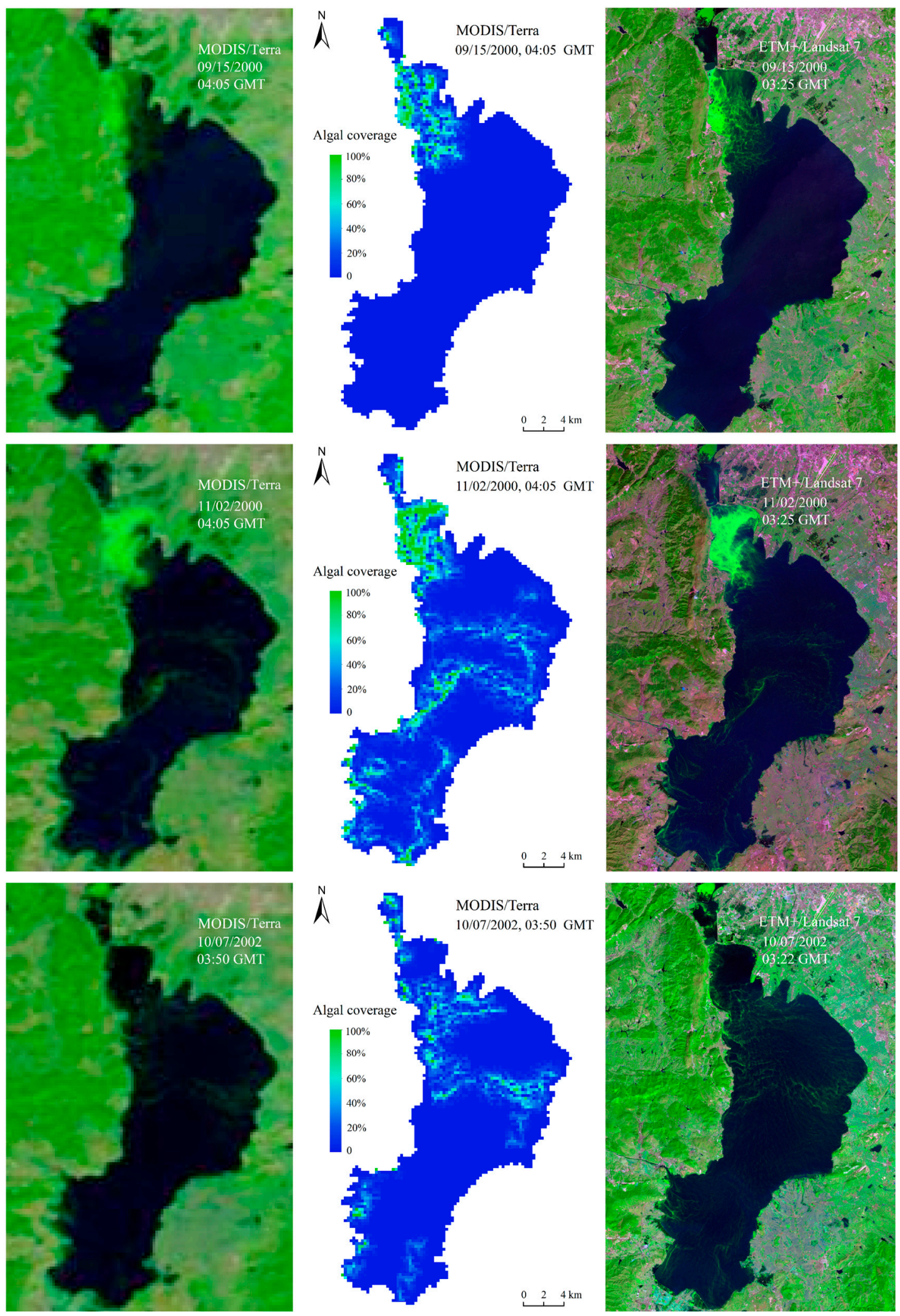

Figure 3. Cont. 

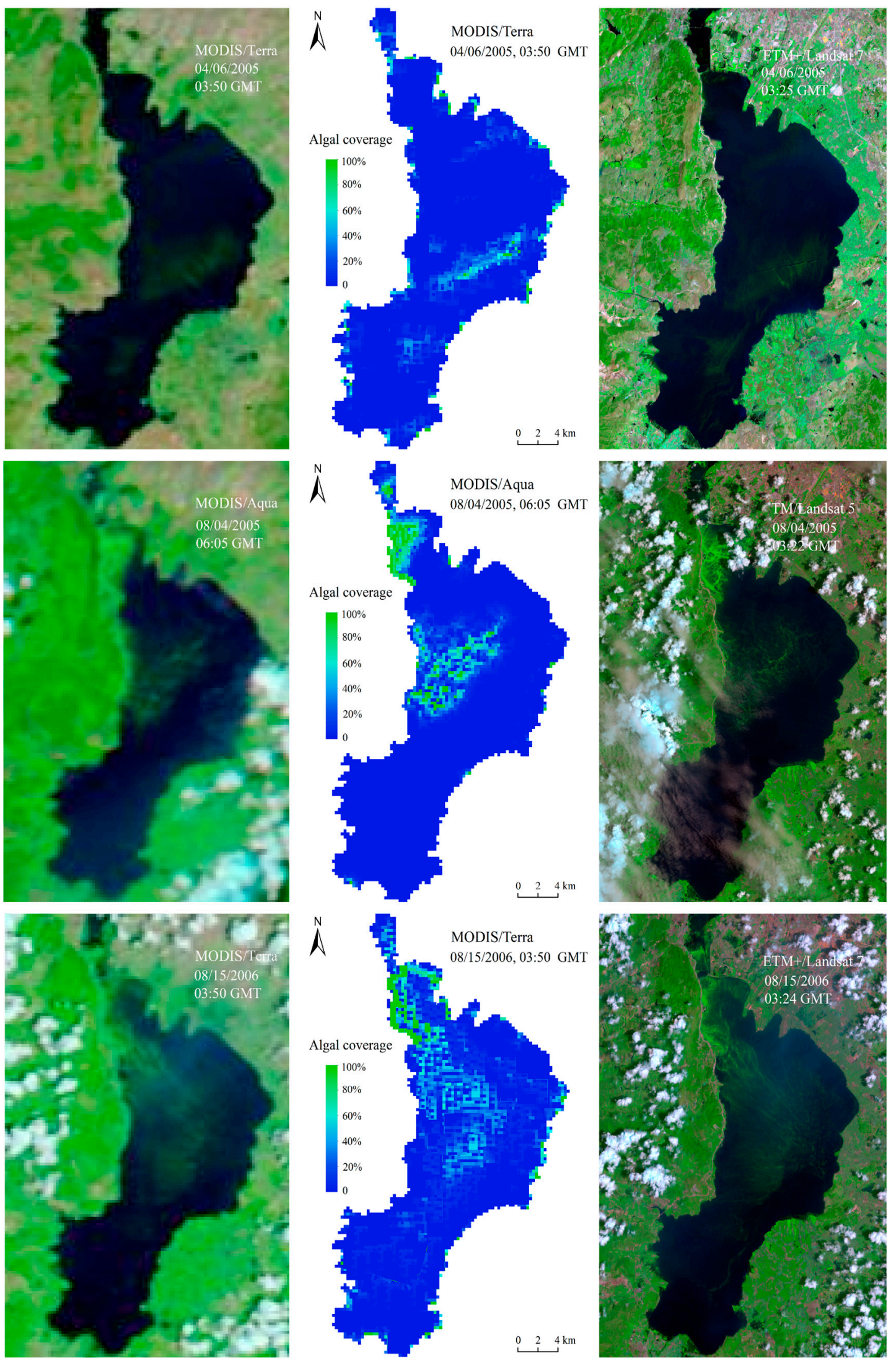

Figure 3. Comparison between algae pixel-growing algorithm (APA) results and Moderate Resolution Imaging Spectroradiometer (MODIS), TM/ETM+ false color composites. 


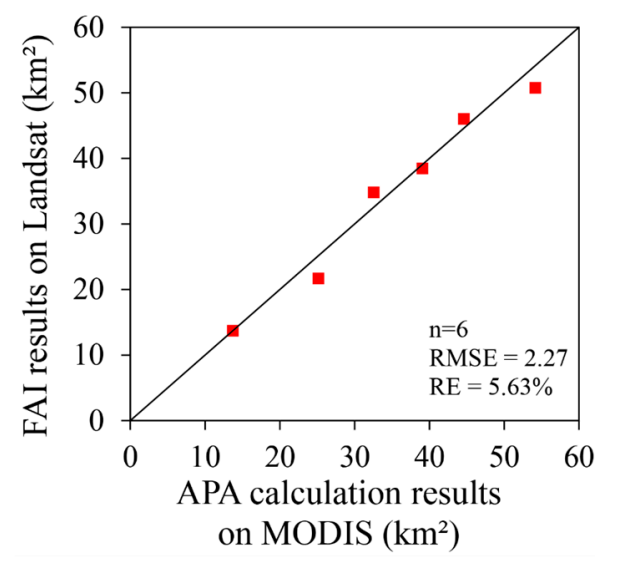

Figure 4. Comparison between the APA results on MODIS and the corresponding six-floating algae index (FAI) results on TM/ETM+ images of algal blooms.

\subsection{Spatial-Temporal Distribution of Algal Blooms}

\subsubsection{Distributions of Algal Bloom Initiation Date and Duration}

The initiation and end dates of algal blooms in Lake Dianchi may not be the same each year. Based on the algal bloom area data and visual interpretation, the initiation dates and durations of algal blooms were determined for each year (Table 3). Each initiation date was transformed into a Julian date format. The MODIS data used in this paper were up to 31 December 2018. However, algal blooms are likely to last until early 2019. Thus, the bloom duration for 2018 could not be determined.

Table 3. Algal bloom initiation and duration of Lake Dianchi from 2000 to 2018 in MODIS images.

\begin{tabular}{cccc}
\hline Year & Initiation Date & End Date & Duration (Days) \\
\hline 2000 & 2000066 & 2001022 & 295 \\
2001 & 2001095 & 2002014 & 285 \\
2002 & 2002039 & 2003025 & 351 \\
2003 & 2003034 & 2003347 & 378 \\
2004 & 2004044 & 2005030 & 350 \\
2005 & 2005055 & 2006010 & 320 \\
2006 & 2006033 & 2007013 & 336 \\
2007 & 2007052 & 2008023 & 334 \\
2008 & 2008096 & 2008359 & 264 \\
2009 & 2009073 & 2010028 & 320 \\
2010 & 2010060 & 2011008 & 313 \\
2011 & 2011095 & 2012043 & 313 \\
2012 & 2012075 & 2013038 & 329 \\
2013 & 2013054 & 2014023 & 344 \\
2014 & 2014071 & 2015028 & 289 \\
2015 & 2015060 & 2016029 & 334 \\
2016 & 2016045 & 2017024 & 345 \\
2017 & 2017047 & 2018021 & 339 \\
2018 & 2018058 & - & \\
\hline
\end{tabular}

Table 3 shows that the initiation dates of algal blooms were mainly distributed within 33-96 days of each year, with a maximum of 40-70 days. Two types of end dates were observed: The first type ended near the end of the year and was mainly distributed between days 347 and 359, and the second type extended to the beginning of the next year.

In Figure 5, the initiation dates of algal blooms in Lake Dianchi demonstrate a wave pattern with a wavelength of approximately four years. The durations were mainly concentrated between 
310-350 days, which were negatively correlated with the initiation date and showed fluctuations with a small amplitude.

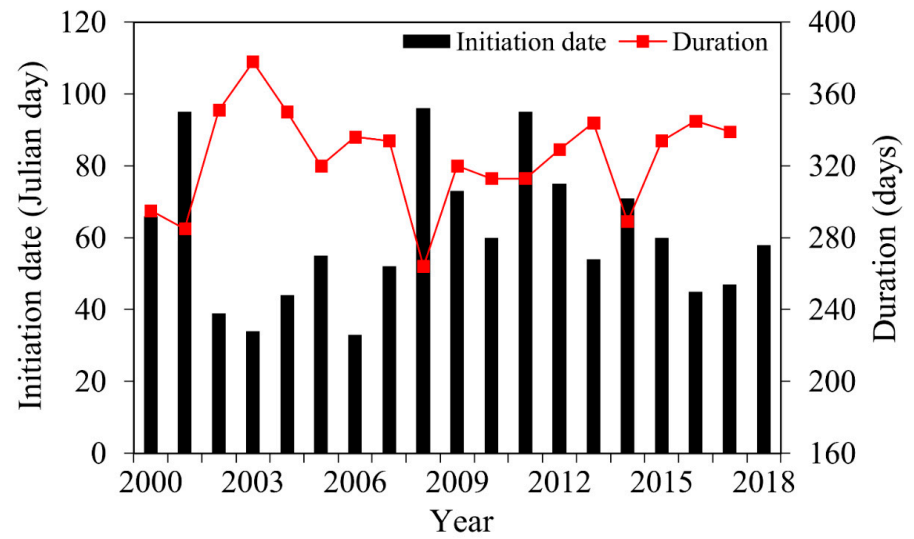

Figure 5. Initiation date and duration changes of algal blooms in Lake Dianchi from 2000 to 2018.

\subsubsection{Temporal Variation of the Algal Bloom Areas}

The existing algal bloom area data are summarized in Figure 6. Although the algal bloom area changed from year to year, the trend increased in summer and decreased in winter. The monthly and annual areas were analyzed individually to better explore the changing trend.

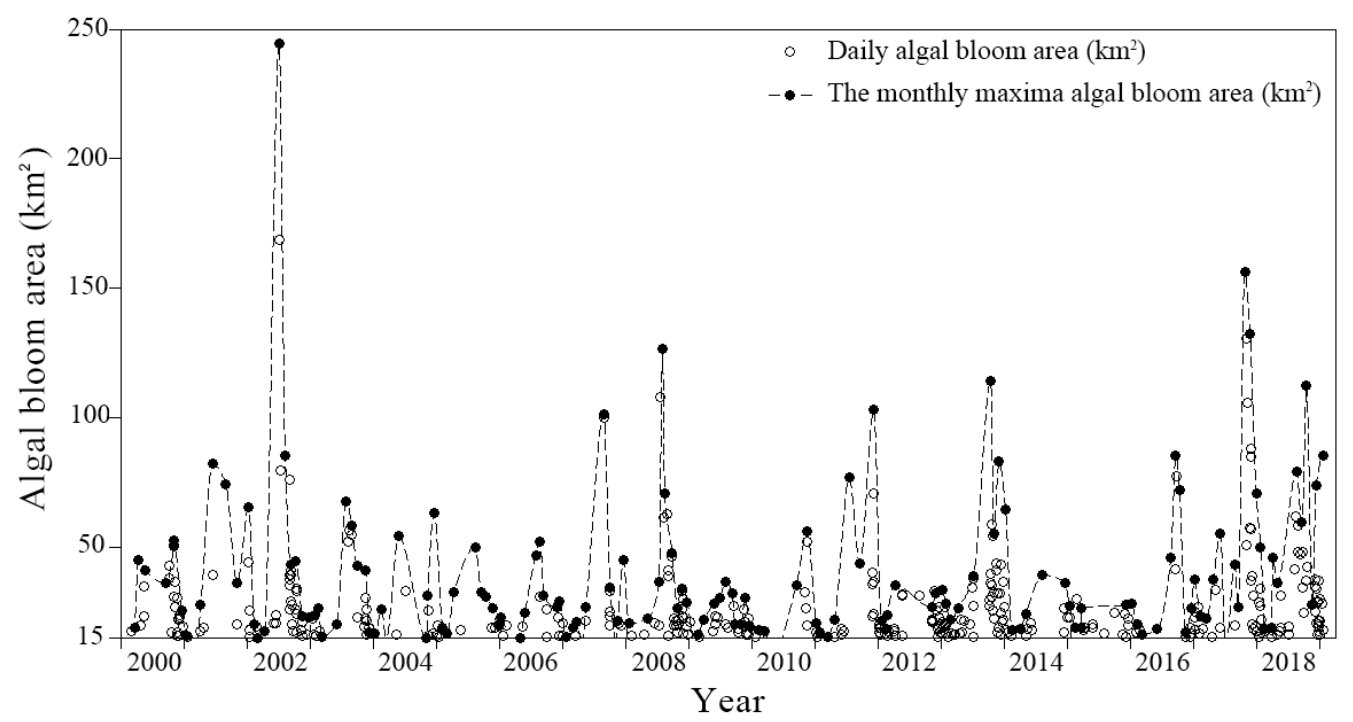

Figure 6. The total algal bloom area changes in Lake Dianchi from 2000 to 2018. The hollow circles represent the daily algal bloom area, and the solid circles represent the maximum algal bloom areas (MaxABs).

Given the influence of wind on the lake surface, the monthly maximum algal bloom areas (MaxABs) were more representative than the monthly average algal bloom areas [41,45]. The MaxABs showed a double-peak trend, with the first peak (higher) appearing in July and the second peak appearing in November (Figure 7a). In general, the algal blooms continued after July, with considerably smaller areas, which was larger than that before July $[13,56]$. 
Monthly maximum algal bloom coverage $\left(\mathrm{km}^{2}\right)$

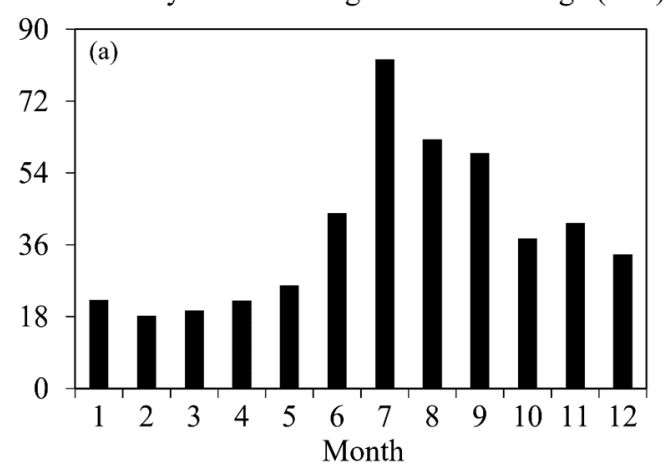

Annual average algal bloom coverage $\left(\mathrm{km}^{2}\right)$

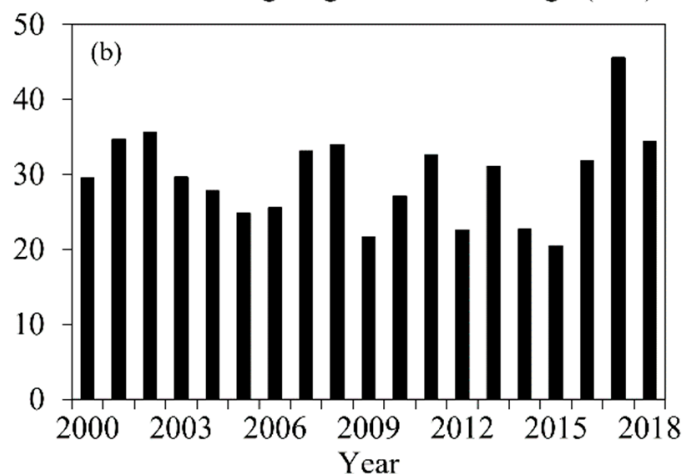

Figure 7. Algal bloom areas changes in Lake Dianchi. (a) MaxABs from January to December; (b) annual variations from 2000 to 2018.

In the annual mean analysis, the apparent spike in 2002 in Figure 6 was excluded as an outlier. The annual average algal bloom coverage of Lake Dianchi in 2000-2018 was then roughly divided into three stages (Figure $7 \mathrm{~b}$ ). The area in 2000-2005 was concentrated between $25 \mathrm{~km}^{2}$ and $35 \mathrm{~km}^{2}$, showing a single peak trend with a small fluctuation range. In 2006-2015, the algae area fluctuation period was shortened to four years, and the fluctuation range was increased to $20-34 \mathrm{~km}^{2}$. Finally, the area in 2016-2018 increased significantly, considerably exceeding the average of the previous years.

Figure 8 shows that the monthly area of algae blooms presented noticeable periodic changes, and the annual changes were almost the same. The area changed synchronously with the monthly average area, which was remarkably bimodal. In summer, the algal bloom area was the largest, after which it decreased to a second peak in autumn and continued to decline until the beginning of the next year.

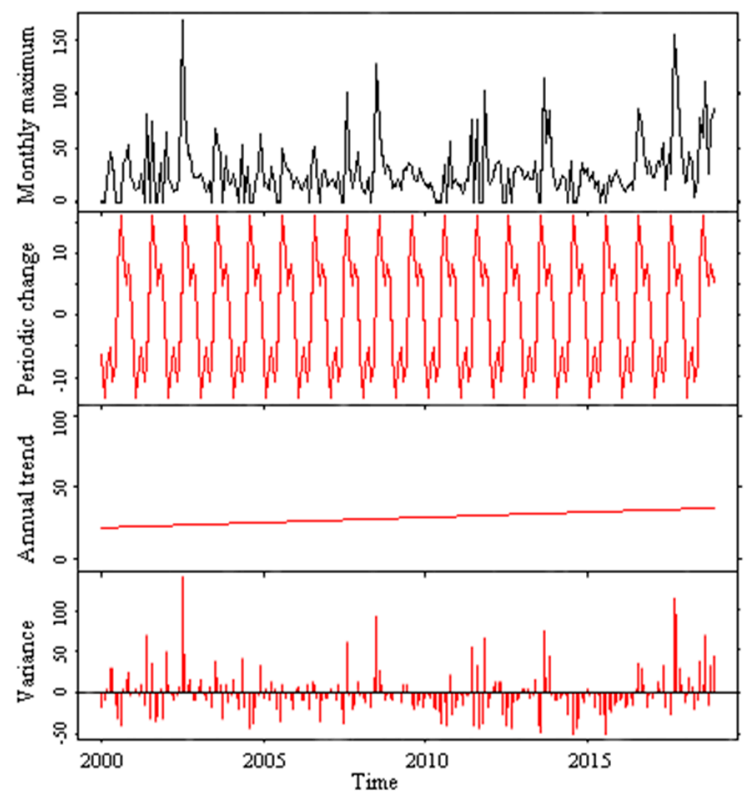

Figure 8. Variation in the monthly maximum values of the algal bloom area in Lake Dianchi for 2000-2018.

Referring to the standard grading division of cyanobacteria blooms in Lake Taihu [55], the algal blooms in Lake Dianchi were classified according to the bloom area. Slight, moderate, and severe algal bloom conditions were defined as blooms with an area $5 \%$ (approximately $15 \mathrm{~km}^{2}$ ), $10 \%$ (approximately $30 \mathrm{~km}^{2}$ ), and 15\% (approximately $46 \mathrm{~km}^{2}$ ) of Lake Dianchi's area, respectively (Figure 9). The occurrence 
day trends of the light and moderate algal blooms tended to be consistent with the total number of days, whereas the severe outbreak days fluctuated in a four-year cycle. Lake Dianchi was dominated by light algal blooms supplemented by moderate algal blooms. In 2008 , severe algal blooms suddenly emerged, and the duration of these blooms increased significantly in 2017 and 2018, exceeding $20 \%$ of the total algal bloom days.

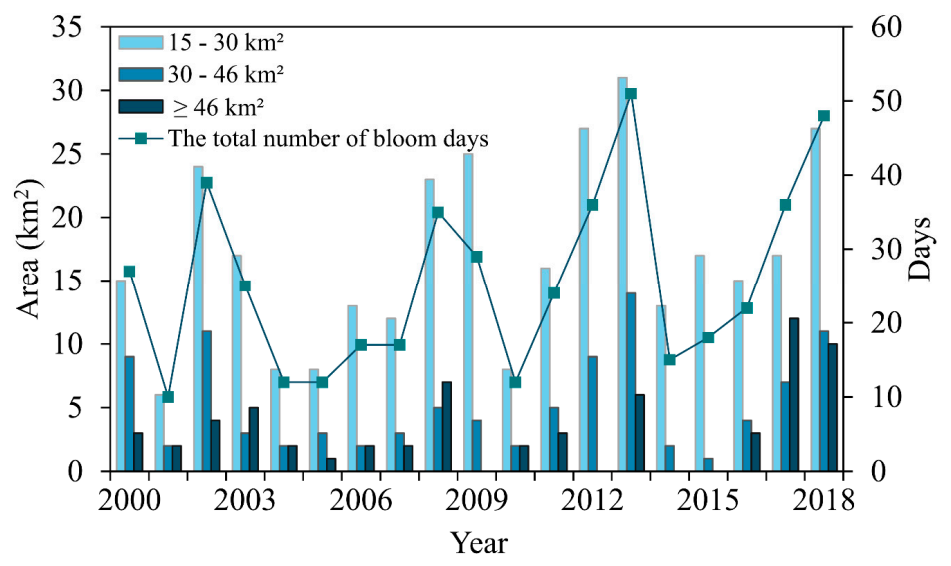

Figure 9. Duration in days for algal blooms with different areas in Lake Dianchi during 2000-2018.

\subsubsection{Temporal-Spatial Distributions of Pixel-Algae Frequency}

The occurrence frequency of algal bloom pixels among the pixels in Lake Dianchi showed a noticeable spatial differentiation due to the geographical differences in the water quality, meteorological, and distance from the city. The temporal-spatial clustering of the average pixel algal bloom frequency (ABF) from January to December (Figure 10a) and from 2000 to 2018 (Figure 10b) was measured by Ward's minimum variance of hierarchical clustering to reveal the spatial heterogeneity pattern between pixels. Finally, the frequencies were divided into five categories.
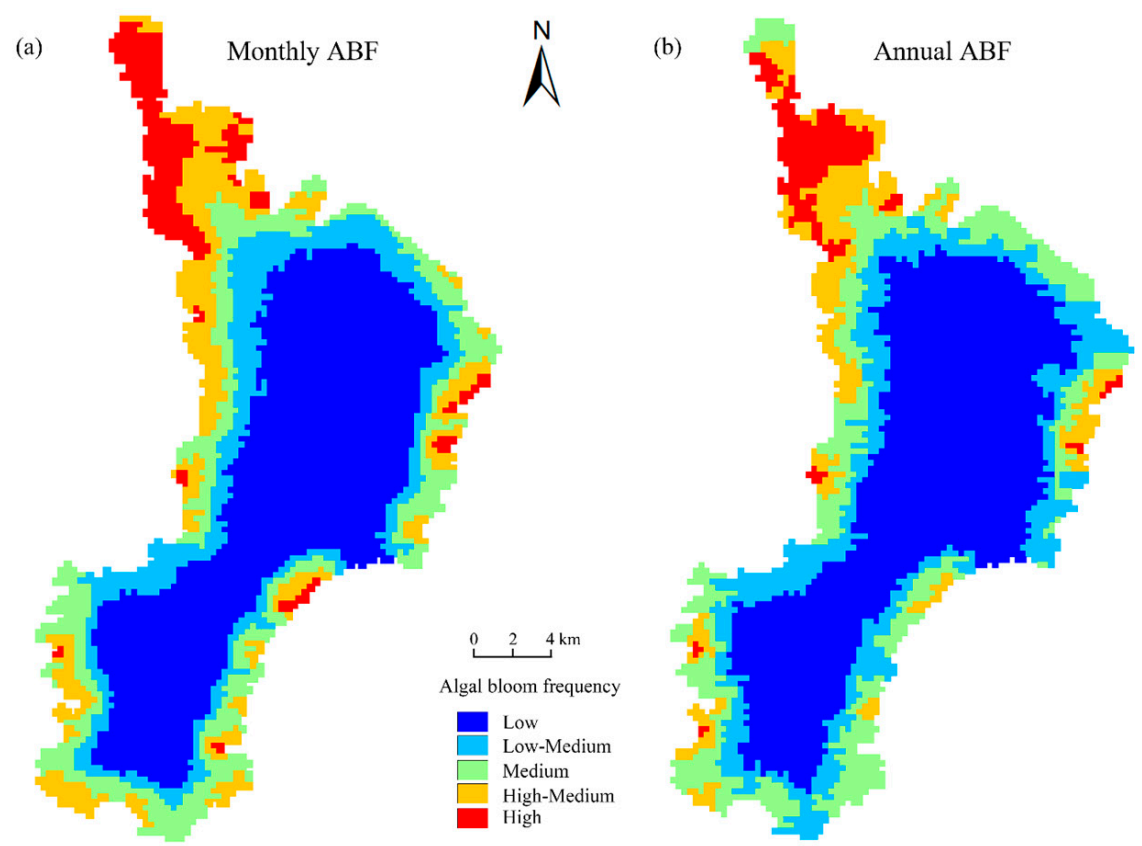

Figure 10. Different algal bloom frequency levels in Lake Dianchi. (a) Monthly frequencies from January to December; (b) annual frequencies from 2000 to 2018. 
Figure 10 shows a remarkable spatial differentiation in the ABF of Lake Dianchi. The distribution trends of the inter monthly and interannual variations are "high in the north and low in the south" and "high at the edge of the lake and low in the center of the lake", respectively. The area with the highest $\mathrm{ABF}$ is the narrow part of the lake in the north. The low and low-middle ABF pixels account for a large proportion of all pixels and are mainly concentrated in the center of the lake, which is wide on the surface. The medium and high-medium ABF pixels serve as the transition region distributed between the high- and low-ABF areas.

Changes in algal blooms are a complex space-time process. Through the analysis of the spatial-temporal trajectory data of algal blooms, we can extract the similarity features of these data and divide them into categories of similar behavior without prior knowledge [57]. A three-dimensional map was used to show the temporal-spatial synchronous variation characteristics [58] of algal blooms in Lake Dianchi. High-ABF areas were utilized as the hot zone to track the trajectory. In Figures 11 and 12, the $x y$ plane represents the ABF spatial distribution in Lake Dianchi, and the $z$-axis represents the temporal distribution information (monthly and yearly sequences). The color scheme only represents the high-ABF hot zones in different months and years and does not represent the ABF level. The ranges of different color schemes projected on the $x y$ plane indicate the high-ABF areas in the current month and year. The projection ranges are plotted with dashed lines. For visual convenience, the monthly and yearly information (represented by Roman numerals) are directly marked on different color planes and projected dashed lines. Based on the change in ABF, the entire lake is divided into three regions: Northern, central, and southern.

Figure 11 shows that the algal blooms were mainly distributed in Caohai and the northern part of Waihai, with the highest frequency of occurrence in one year. As seen in the projection of the xy plane, the frequency was the most convergent in February-March, gradually expanded southward in April, extended to the central region in July-September, and then returned to the north from October to January of the following year. The central section showed sporadic outbreaks. Hot spots appeared at the edge of the lake, and an internal expansion trend was evident in August. In the southern region, the high-ABF hot spots were the lowest in one year and all concentrated on the edge of the lake body.

The interannual change characteristics (Figure 12) were as follows (from the projection of the xy plane): The interannual variation in the ABF of Lake Dianchi was similar to that of the monthly variation. The northern region remained a high- $\mathrm{ABF}$ area, and the highest $\mathrm{ABF}$ occurred in 2000, 2002, and 2018. In the other years, the northwest border showed a high-incidence trend, and the northernmost end had a high-occurrence trend in 2010, 2011, and 2014. In all years, the central region showed sporadic bursts along the lacustrine margin, and high-ABF were mainly concentrated in the northeast-southwest trending part of the middle-eastern margin. The southern region had a few high-ABF outbreaks, and small hot spots were distributed in the depressed area at the edge of the lake body. 


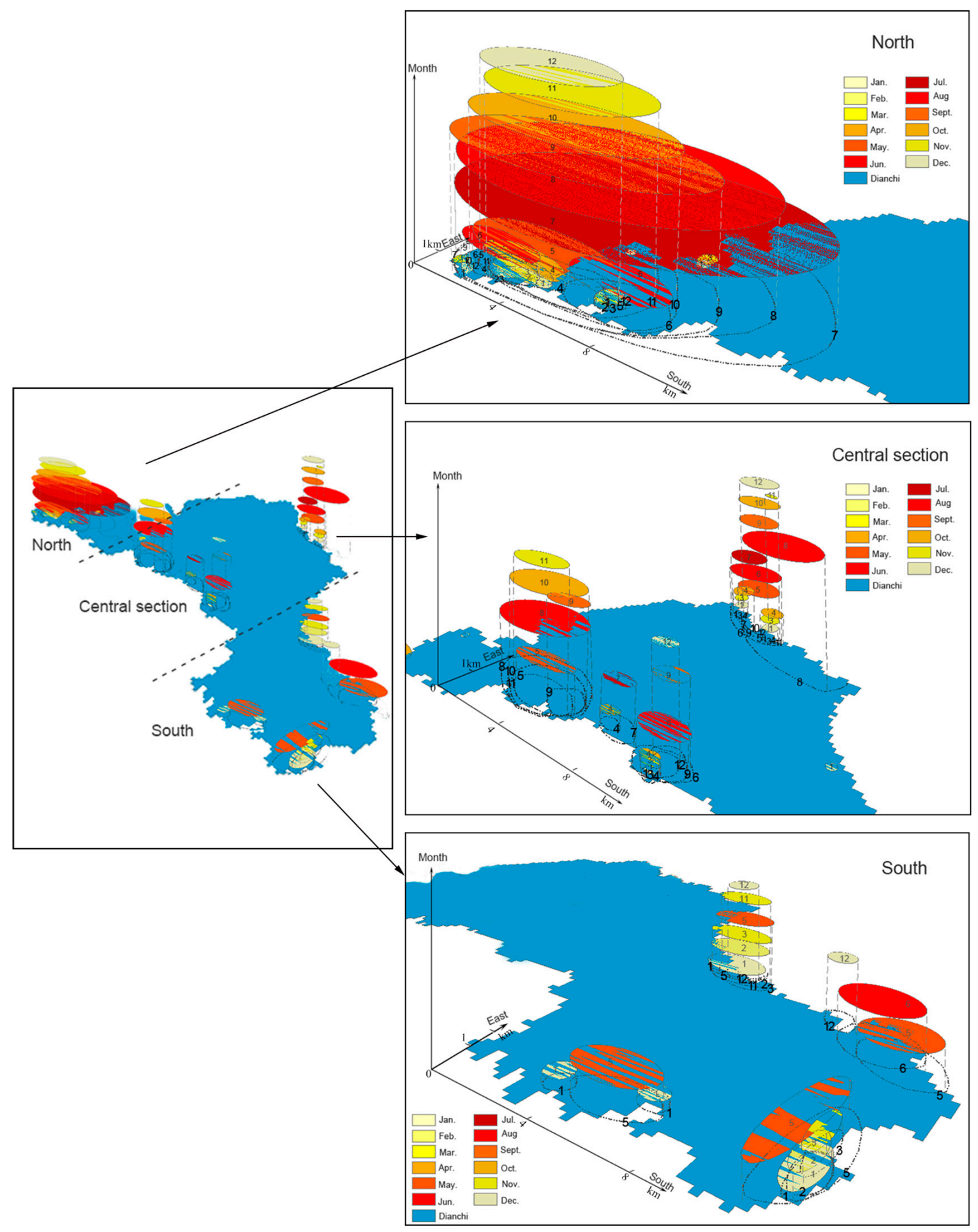

Figure 11. Variation in the spatiotemporal trajectory of monthly high-ABF areas in Lake Dianchi. 1-12 Numbers represent January to December. 


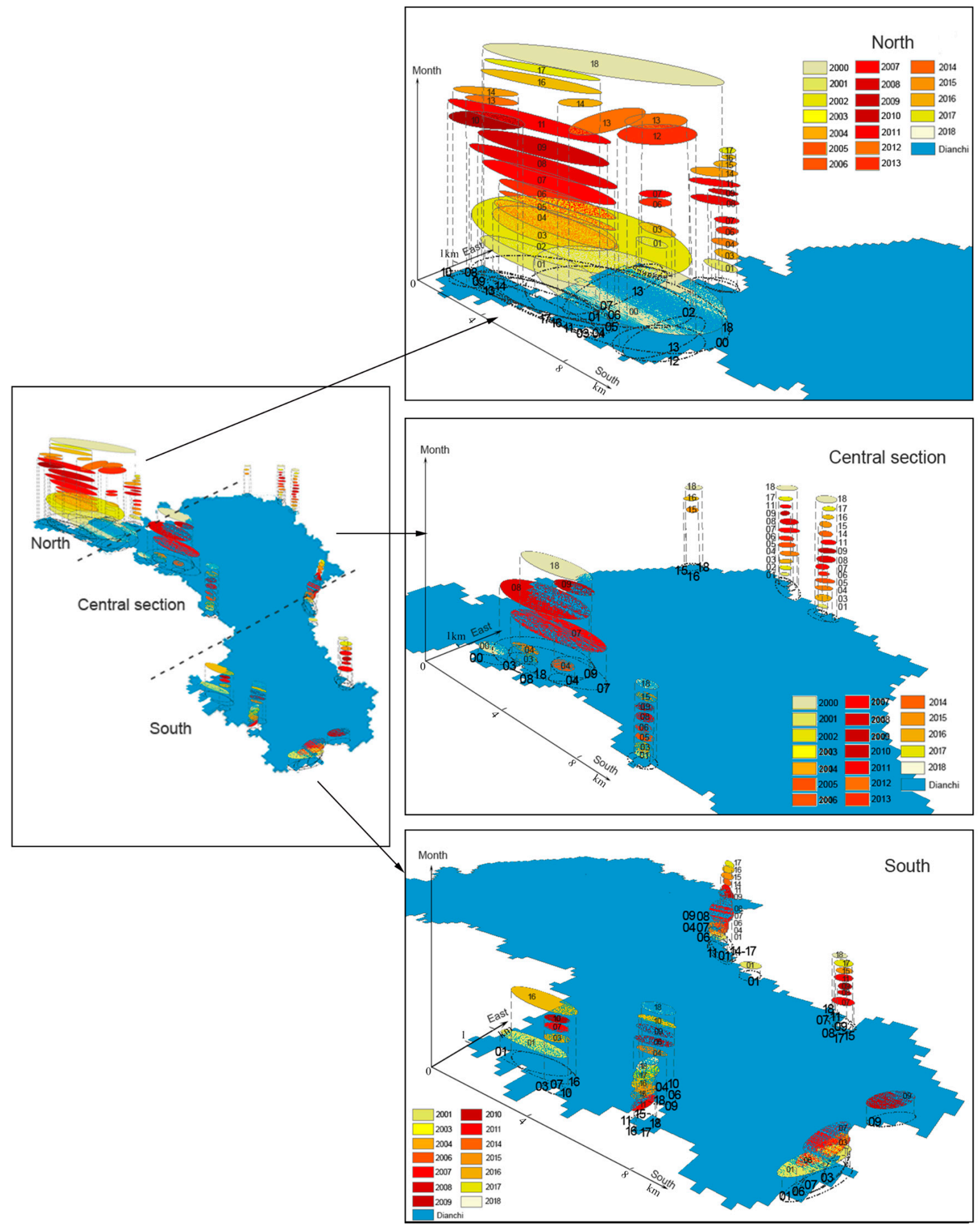

Figure 12. Variation in the spatiotemporal trajectory of the annual ABF in Lake Dianchi during 2000-2018. Numbers 00-18 are shorthand terms for 2000-2018.

\subsection{Influencing Factors of Algal Blooms}

Many studies have shown that, in addition to nutrient elements, meteorological factors affect the temporal-spatial dynamics of algal blooms $[5,26,28,32,44,52]$. But the effect of joint parameters has been studied less than that of individual parameters, and identification factors are more qualitative or semi-quantitative [5]. Therefore, we used principal component analysis (PCA) to investigate the 
combined effects of water quality and meteorological factors on the growth of algal blooms more quantitatively from the perspective of daily, monthly, and interannual scales.

\subsubsection{Daily Influencing Factors of Algal Blooms}

The nutrient levels in the lake are affected by the dry and rainy seasons [27]. Except for heavy rain, snow melting, and other sudden water pollution and ecological events, the daily changes in water quality are not significant. Besides, water quality data from different monitoring spots may be different and not representative of the entire lake $[24,59,60]$. But the local meteorological elements are uniform in Lake Dianchi. Favorable meteorological conditions, such as high temperature, strong light, and low WS, promote the floatation and accumulation of algal blooms [35,61]. High temperatures are beneficial in that they accelerate the transformation of organic matter into inorganic nutrient elements in sediments, thereby providing a material basis for the sustained and rapid growth of algae [24]. The average WT of shallow lakes is consistent with $\mathrm{T}_{\text {mean }}$, and an increase in WT benefits the recovery and growth of overwintering algae [24,62]. Solar radiation is the energy source of cyanobacteria [63]. Light affects factors such as the synthesis, physiological activity, and buoyancy regulation of algae [24,63-65]. Moreover, wind is an important regulator of algae formation and expansion [66,67]. Therefore, PCA was used to analyze the significant differences between daily algal bloom areas and WT, WS, and SH [30,45] in 2000-2005, 2006-2015, and 2016-2018 (Figure 13). The correlation is expressed by the cosine value of the angle between any two axes in the graph, while the influence intensity is expressed as the distance one axis projected on another. The longer the projection length, the stronger the correlation.
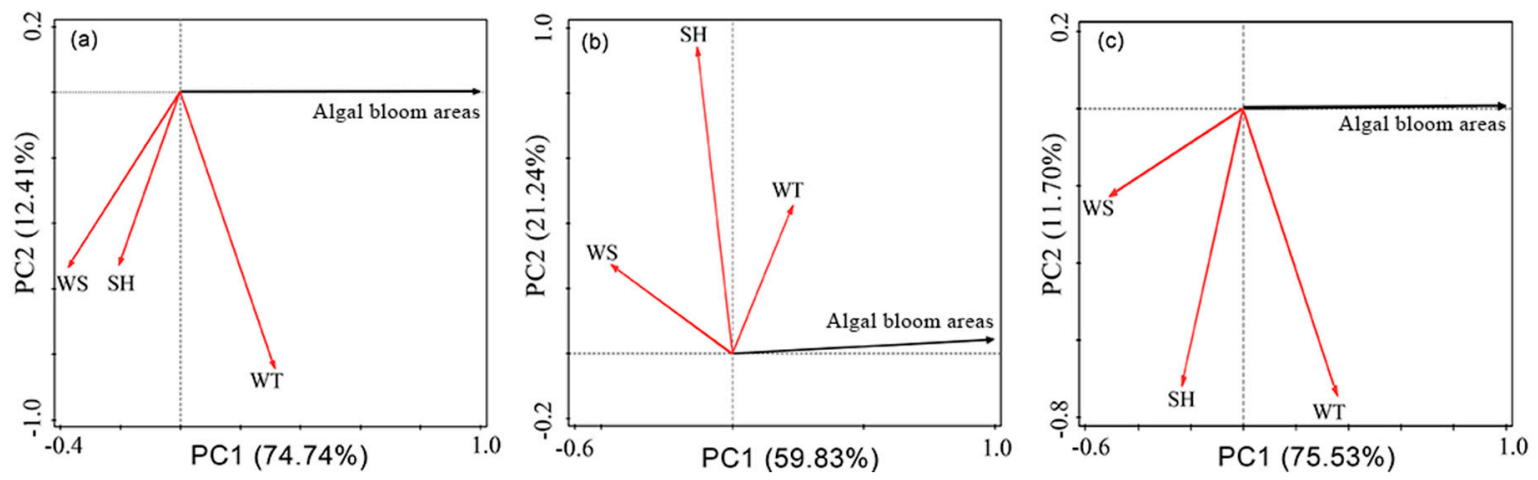

Figure 13. Principal component analysis (PCA) ordination diagram of daily algal blooms in Lake Dianchi. (a) 2000-2005; (b) 2006-2015; and (c) 2016-2018.

In general, the acute angles showing positive correlations between algal bloom areas and WT, while the obtuse angles showing significant negative correlations between the algal bloom areas and WS, which have been confirmed in previous studies $[29,39,46,68,69]$. Also, the influence of WS on algal bloom areas shows an increasing trend. Besides, the angles between the algal bloom areas and $\mathrm{SH}$ are close to right angles, which denotes an insignificant relationship or a weak negative correlation.

\subsubsection{Monthly Influencing Factors of Algal Blooms}

In addition to the factors mentioned above, the monthly influencing factors also added water quality and other meteorological parameters in the comprehensive analysis (the $\mathrm{pH}, \mathrm{COD}_{\mathrm{Mn}}, \mathrm{DO}$, $\mathrm{NH}_{3}-\mathrm{N}$, and WT data for 2000-2005 were not collected. Thus, the water quality data for this phase considered only TN, TP, and TN/TP) (Figure 14). 

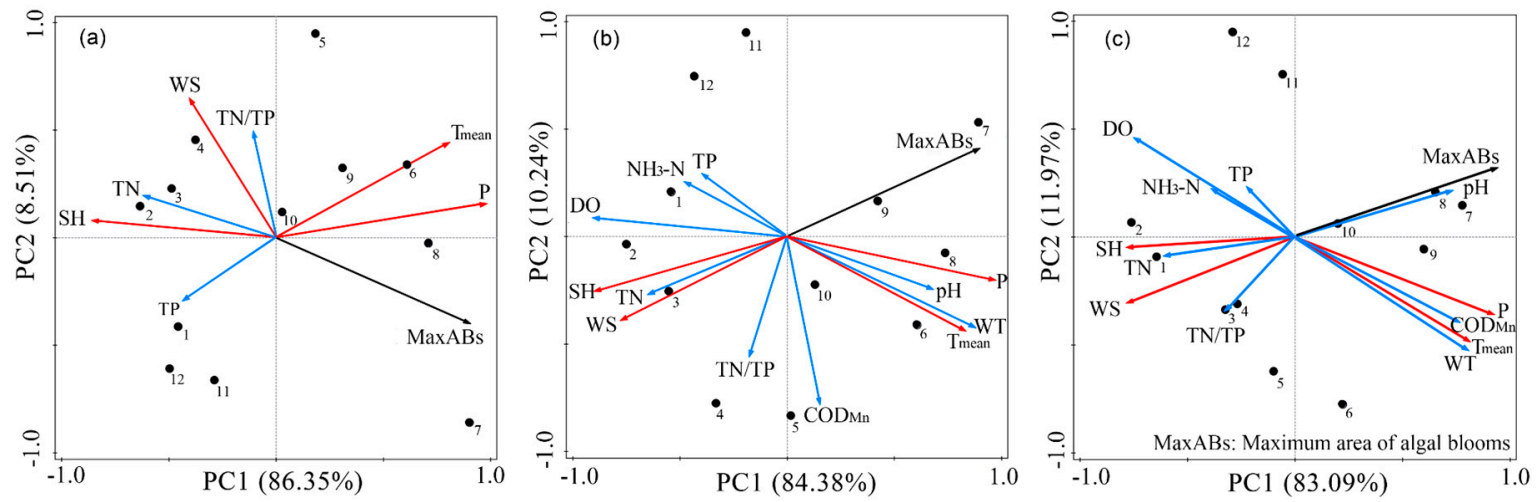

Figure 14. PCA ordination diagram of monthly algal blooms in Lake Dianchi. (a) 2000-2005; (b) 2006-2015; and (c) 2016-2018. Hollow circles, monthly algal bloom variables; red arrows, meteorological parameters; blue arrows, water quality parameters.

In these three periods, meteorological factors were expressed as the first principal component, while water quality parameters were identified as the second component. The algal bloom areas, $\mathrm{P}$, and $\mathrm{T}_{\text {mean }}$ had a generally significant positive correlation, and further observation showed that the effect of $\mathrm{P}$ was greater than that of $\mathrm{T}_{\text {mean }}$. The positive influencing factors of water quality are $\mathrm{WT}$ and $\mathrm{pH}$, and the effect of $\mathrm{pH}$ on the algal bloom areas gradually increases every five years. The rest of the factors harm the growth of algal blooms, among which, WS and SH are the most important factors. The southwest and southeast monsoons prevail in the Lake Dianchi Basin (Figure 15), especially west-southwest, which may contribute to the distribution of algal blooms mainly in Caohai and the north of Waihai.

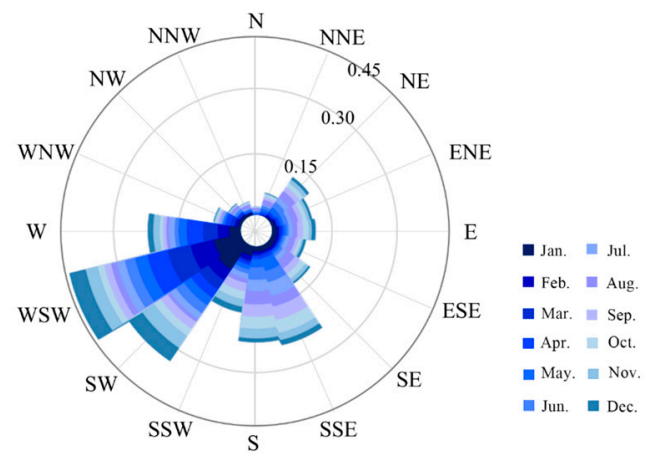

Figure 15. Statistical rose map of the monthly wind direction (WD) of Lake Dianchi in 2000-2018.

\subsubsection{Yearly Influencing Factors of Algal Blooms}

Figure 16 shows the average difference in meteorological and water quality parameters from 2000 to 2018. The average difference between $\mathrm{T}_{\text {mean }}, \mathrm{T}_{\max }, \mathrm{T}_{\min }, \mathrm{P}, \mathrm{WS}, \mathrm{SH}, \mathrm{TN}, \mathrm{TP}, \mathrm{TN} / \mathrm{TP}, \mathrm{pH}, \mathrm{DO}, \mathrm{COD}_{\mathrm{Mn}}$, $\mathrm{NH}_{3}-\mathrm{N}$, and WT and the corresponding mean values are expressed by $\Delta \mathrm{T}_{\text {mean }}, \Delta \mathrm{T}_{\max }, \Delta \mathrm{T}_{\min }, \Delta \mathrm{P}, \Delta \mathrm{WS}$, $\Delta \mathrm{SH}, \Delta \mathrm{TN}, \Delta \mathrm{TP}, \Delta \mathrm{TN} / \mathrm{TP}, \Delta \mathrm{pH}, \Delta \mathrm{DO}, \Delta \mathrm{COD}_{\mathrm{Mn}}, \Delta \mathrm{NH}_{3}-\mathrm{N}$, and $\Delta \mathrm{WT}$, respectively. Both meteorological and water quality factors showed inapparent fluctuations in the past 19 years. The variations in $\mathrm{T}_{\text {mean }}$ and $\mathrm{T}_{\max }$ in the past 19 years are similar, with fluctuation cycles that first gradually shortened from five years to three years and then stabilized after 2016. The fluctuation cycle of $\mathrm{T}_{\min }$ increased gradually from three years to six years, while $\mathrm{T}_{\min }$ of 2018 was $0.8^{\circ} \mathrm{C}$ lower than that of 2000 in general. The precipitation can be divided into three stages: Relatively stable in 2000-2008, a yearly increase in 2009-2016, and a noticeable decrease in 2017-2018, with $1 \mathrm{~mm}$ less than that of 2000. The change in WS can also be divided into three stages: An annual increase in 2000-2006, a decreasing and then increasing trend in 2007-2010, and an annual decrease to the average value in 2011-2018. The SHs was lower than the average value until 2012, after which it was higher than the average. The changes 
in TP and TN from year to year were nearly opposite, but both showed an overall downward trend. The change of TN/TP and TN were approximately similar. PH and WT did not change considerably, except for a few years. DO showed a decreasing trend before 2011, after which DO increased annually by $0.2 \mathrm{mg} / \mathrm{L}$. COD $\mathrm{Mn}$ presented a more balanced fluctuation in the vicinity of the mean value. $\mathrm{NH}_{3}-\mathrm{N}$ was stable after 2010.
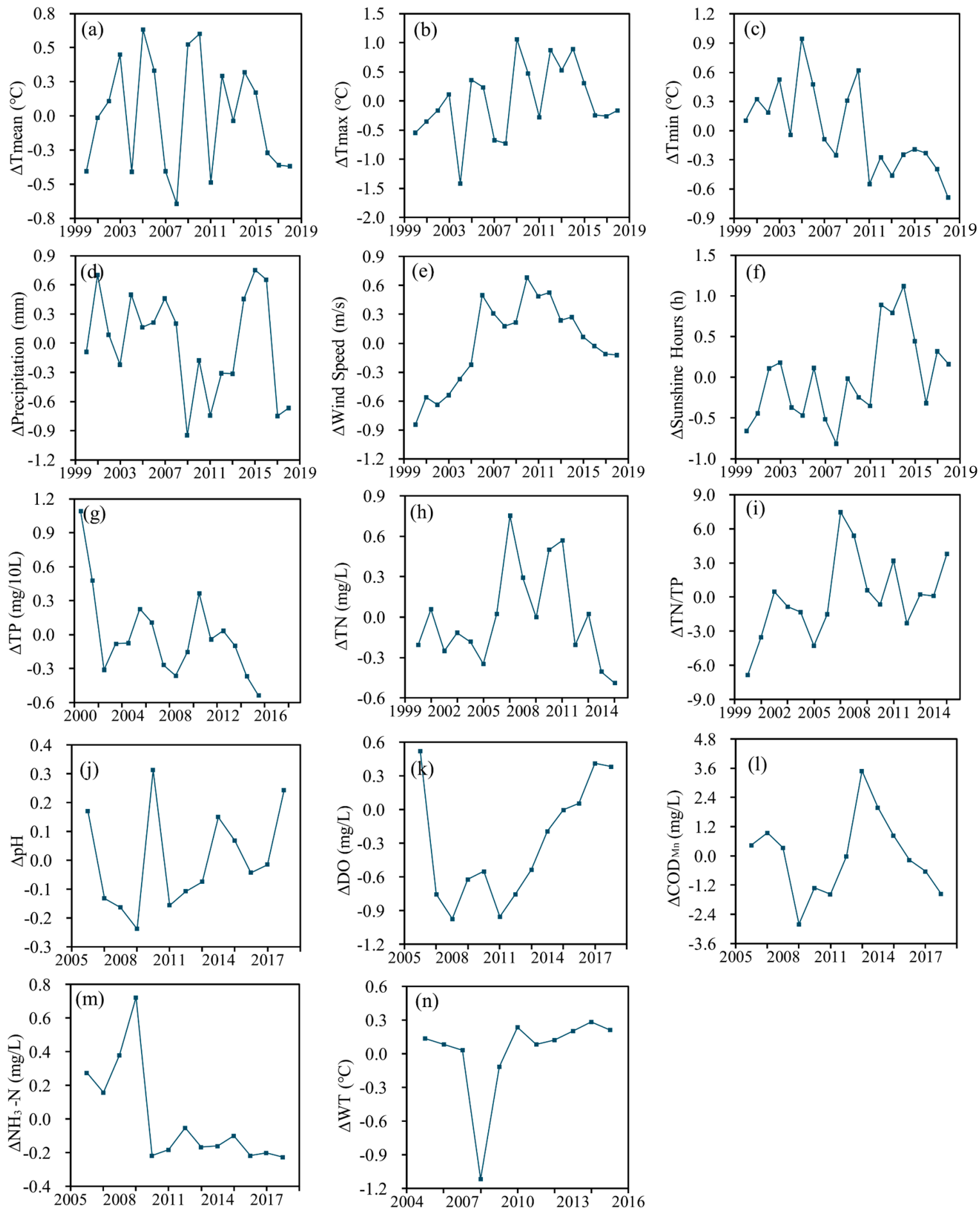

Figure 16. Trends in annual average anomalies of (a) mean temperature; (b) maximum temperature; (c) minimum temperature; (d) precipitation; (e) wind speed; (f) sunshine hours; (g) TP; (h) TN; (i) TN/TP; (j) $\mathrm{pH}$; (k) DO; (l) $\mathrm{COD}_{\mathrm{Mn}}$; (m) $\mathrm{NH}_{3}-\mathrm{N}$; and (n) WT during 2000-2018 in Lake Dianchi. 
After characterizing the changes in environmental parameters in the past 19 years, we analyzed the interannual variation of algal blooms and environmental factors in Lake Dianchi by PCA. Figure 17a shows the general variation trends of algal blooms and environmental parameters during 2000-2018. The sample data for each year are grouped, and the results are consistent with the results for 2000-2005, 2006-2015, and 2016-2018. Subsequently, the three time periods were analyzed separately. Figure 17b shows the significant algal blooms in 2000-2005 was mainly affected by the positive influence of TN

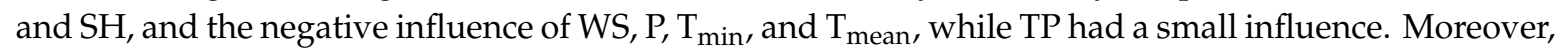
$\mathrm{TN} / \mathrm{TP}$ and $\mathrm{SH}$ and TP, TN, and $\mathrm{P}$ had strong positive and negative effects on duration; this finding is contrary to the initiation date. In 2006-2015 (Figure 17c), the change trends of significant algal blooms and the ABF were similar. The positive effect of TN, TN/TP, COD $\mathrm{Mn}_{\text {, }}$ and TP on S-days and ABF was weakened, whereas the negative effect of $\mathrm{pH}, \mathrm{T}_{\min }, \mathrm{DO}, \mathrm{SH}, \mathrm{T}_{\max }$, and $\mathrm{T}_{\text {mean }}$ was strengthened. Meanwhile, WT and P only had a small effect. The changes in the duration and initiation date were opposite. The main factor with a positive effect on duration was WT, which was also the main source of the negative effect on initiation date. The changes in the initiation date and duration from 2016 to 2018 (Figure 17d) were consistent with those in the previous years and showed an evident negative correlation. The changes in significant algal blooms and ABF differed from those in previous years but did not have any noticeable correlation. The initiation date and frequency showed a strong positive correlation. $\mathrm{SH}, \mathrm{DO}, \mathrm{NH}_{3}-\mathrm{N}$, and $\mathrm{pH}$ had a positive effect on significant algal blooms, particularly $\mathrm{SH}$ and DO. In contrast, the negative effect of $\mathrm{WS}, \mathrm{P}$, and $\mathrm{T}_{\text {mean }}$ on significant algal blooms was the greatest, followed by the strong influence of $\mathrm{T}_{\min }$ and $\mathrm{COD}_{\mathrm{Mn}}$. $\mathrm{PH}$ and $\mathrm{T}_{\max }$ had a strong influence on the initiation date and frequency. The higher the $\mathrm{T}_{\max }$ and $\mathrm{pH}$ were, the greater the frequency of severe algal blooms was. The closer $\mathrm{T}_{\max }$ was to summer, the later the initiation date of algal blooms was and the shorter the duration was. The higher the $\mathrm{COD}_{\mathrm{Mn}}$ and $\mathrm{NH}_{3}-\mathrm{N}$ concentrations in the lake were, the longer the algae blooms lasted. Also, the duration mainly depended on the influence of $\mathrm{T}_{\text {min }}$.

We used redundancy analysis (RDA) to extract the main environmental factors on algal blooms for 2000-2018 (Figure 18). After removing the redundant parameters, only three meteorological factors (SH, WS, and $\mathrm{P}$ ) and four water quality factors ( $\mathrm{TN}, \mathrm{TP}, \mathrm{NH}_{3}-\mathrm{N}$, and $\mathrm{DO}$ ) were retained. In general, the initiation date and duration of algal blooms remained significantly negatively correlated, whereas the initiation date, ABF and significant algal blooms were positively correlated. TN had a considerable positive influence on initiation date, ABF, and significant algal blooms, which agrees with previous studies $[5,22,45,54,70]$. The effect of DO was opposite to that of TN, but similar results have not been observed in previous studies. To verify this finding, more years of DO sampling data are needed [5]. Also, the negative effects of $\mathrm{SH}, \mathrm{TP}$, and WS were weakened. $\mathrm{NH}_{3}-\mathrm{N}$ only had a small effect on the three parameters. Meanwhile, DO, SH, and TP were the main positive factors on duration, while WS had no noticeable effect on it.

The WS of Lake Dianchi was counted based on the WD (Figure 19a), and the WD was measured based on the frequency of wind occurrence (Figure 19b). A wind rose map showed that the annual WS was between 1.65 and $3 \mathrm{~m} / \mathrm{s}$, which had a minimal effect on the disturbance of the lake water. The statistical results of WD in 2000-2018 are the same as the monthly findings. Southwest wind, especially west-southwest WD, was dominant, which may be the reason for the high frequency of algal blooms in the north of Lake Dianchi [5,13,35]. 

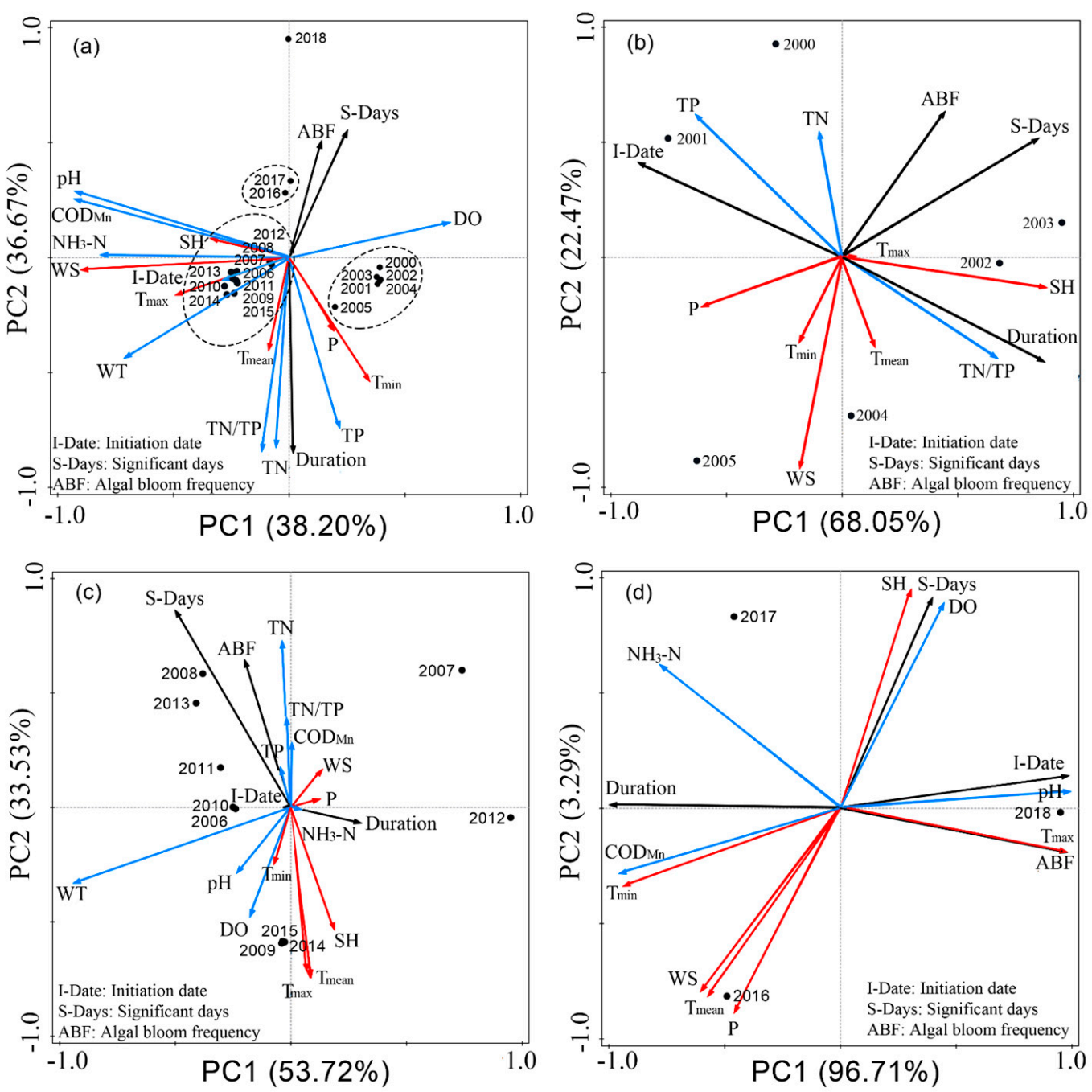

Figure 17. PCA ordination diagram of interannual algal blooms in Lake Dianchi. (a) 2000-2018; (b) 2000-2005; (c) 2006-2015; and (d) 2016-2018. Black points, interannual algal bloom variables; black arrows, algal bloom variables; red arrows, meteorological parameters; and blue arrows, water quality parameters.

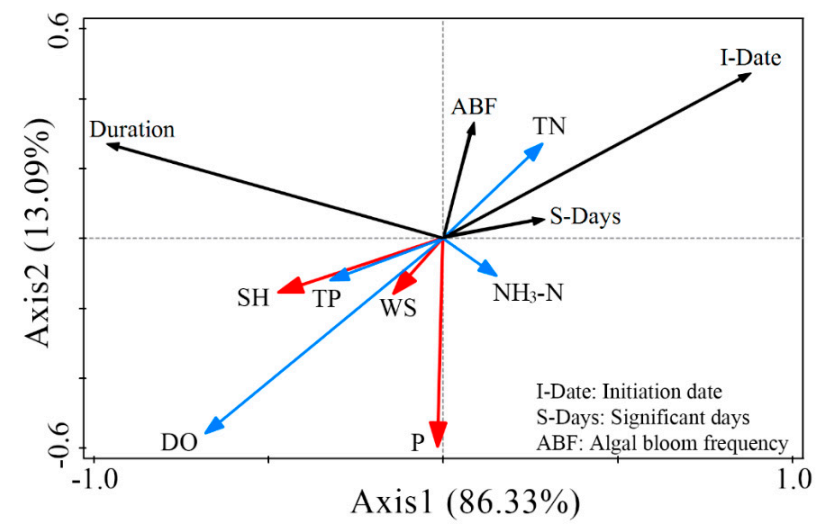

Figure 18. Redundancy analysis (RDA) ordination diagram of interannual algal blooms in Lake Dianchi during 2000-2018. Black arrows, algal bloom variables; red arrows, meteorological parameters; and blue arrows, water quality parameters. 

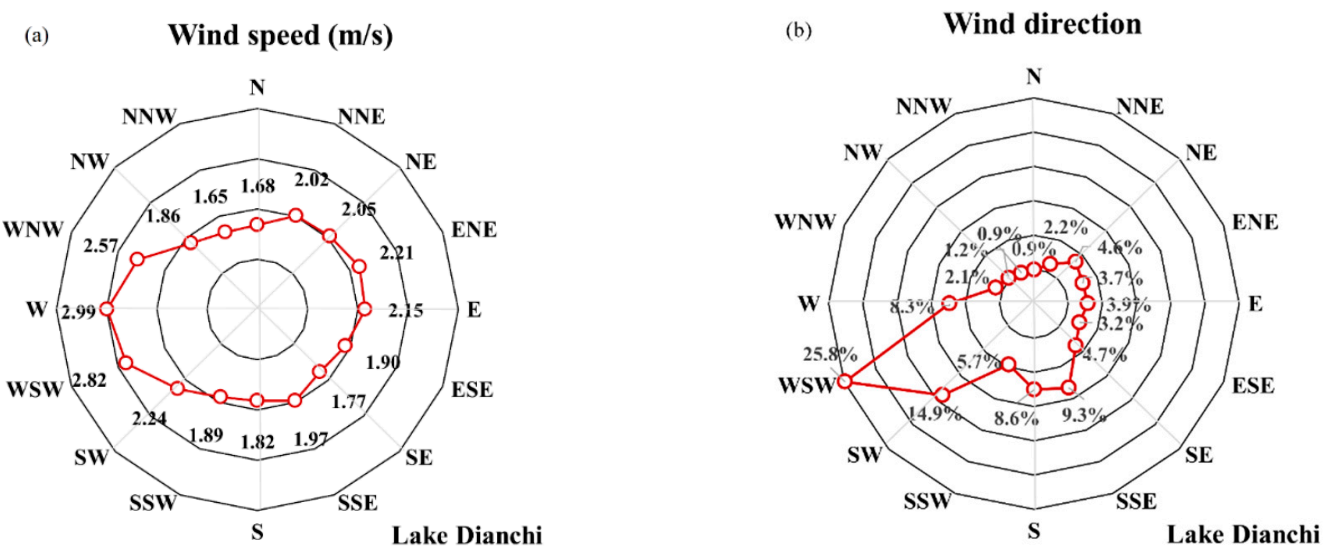

Figure 19. Statistical rose maps of interannual winds in Lake Dianchi during 2000-2018. (a) Wind speed; (b) wind direction.

\section{Discussions}

\subsection{Meteorological and Water Quality Drivers}

The influence of single water quality parameters on algal blooms is greater than that of meteorological factors, among which, TN and TP are the most commonly used in studies $[5,27,71,72]$. But in our research, we found out that the meteorological factors were expressed as the first principal component, while water quality parameters were identified as the second component in monthly influencing results. Also, meteorological factors and water quality factors account for a considerable proportion of interannual influencing factors.

Some studies have shown that $\mathrm{pH}>8.5[5,73,74]$ and $\mathrm{WT}>20^{\circ} \mathrm{C}[75,76]$ are conducive to the growth of cyanobacteria. The $\mathrm{pH}$ of Lake Dianchi has reached the optimum level for the growth of cyanobacteria, with a monthly average of $8.56(2006-2015,8.54 ; 2016-2018,8.63)$. The $\mathrm{pH}$ of 2016-2018 is 0.1 higher than that of 2006-2015 and is beneficial to the proliferation of algal blooms. In this plateau Lake Dianchi, the annual $\mathrm{T}_{\text {mean }}$ is approximately $20^{\circ} \mathrm{C}$ and does not change considerably, the WT can be greater than $20^{\circ} \mathrm{C}$ from May to August [5], which provides suitable conditions for the growth of algal blooms. Also, high summer temperature is conducive to the occurrence of algal blooms, which confirms the phenomena observed in Caohai or the entire Lake Dianchi $[5,27,74]$.

We found out that the effect of $\mathrm{P}$ was greater than that of $\mathrm{T}_{\text {mean }}$, which might be supported by two mechanisms: First, the increased effect of P may be related to the location of Lake Dianchi, which accepts 29-river inputs of the surrounding areas [77], with only one outlet [13]. When the precipitation increases, the surface runoff carries a large number of terrestrial pollutants, especially nitrogen and phosphorus, into the lake [22]. Second, pollutants in the air descend to the lake surface through precipitation [39,78], representing none-point source pollution [13]. Either mechanism increases the concentrations of pollutants and nutrients in the lake, affecting chemical and biological processes [79] and providing a material basis for the growth and reproduction of algae.

WS and $\mathrm{SH}$ are the most important negative factors, which are consistent with previous studies [5,45]. Some studies have shown that WS affects the mixing mode of surface lake water and determines the success or failure of algae floating from the water column to the water surface. When the WS exceeds $4 \mathrm{~m} / \mathrm{s}$, a shallow lake can be mixed by full turbulence, and the vertical floating migration of blue algae can be effectively suppressed [79]. When WS $<3 \mathrm{~m} / \mathrm{s}$, the interference to the water body is small and affected by the floating characteristics of algae. Once blue algae overgrow and float to the surface of a lake, the algae will accumulate in a certain spatial range, resulting in the formation of large areas of algal blooms [5]. The WS $<3.5 \mathrm{~m} / \mathrm{s}$ of Lake Taihu was beneficial to the emergence of cyanobacteria from 2001 to 2013 [45]. Meanwhile, the average WS of Lake Dianchi from 2000 to 2018 was only $2.3 \mathrm{~m} / \mathrm{s}$, which was highly conducive to the creation of a calm surface 
layer [5], resulting in large areas of algal blooms. Also, regional circulation formed by wind has a great influence on the occurrence, development, and diffusion of cyanobacteria blooms $[5,13,45]$. The southeast and southwest monsoons prevail in the Lake Dianchi Basin, especially west-southwest, which may contribute to the distribution of algal blooms mainly in Caohai and the north of Waihai. This result is consistent with existing findings $[5,13,22]$. Additionally, the solar radiation in the low latitude plateau of Lake Dianchi is sufficient for cyanobacteria growth, while the low self-shading and high-intensity light inhibit the growth of cyanobacteria [27].

A previous study suggested that the growth of algal blooms is not limited by the concentration of nutrients in the water when the nutrients are sufficient ( $\mathrm{TN} \leq 0.80 \mathrm{mg} / \mathrm{L}, \mathrm{TP} \geq 0.20 \mathrm{mg} / \mathrm{L}$ ) [80]. On a monthly scale of our research, the negative influences of $\mathrm{DO}, \mathrm{TN}, \mathrm{TN} / \mathrm{TP}, \mathrm{NH}_{3}-\mathrm{N}$, and TP on algal blooms were generally weakened in Lake Dianchi. This weakening may be related to the fact that the TN and TP contents in Lake Dianchi exceed the internationally recognized threshold of eutrophication $[13,22]$. The negative correlation was inferred to be mainly due to the consumption of nitrogen, phosphorus, and DO by algal blooms in the lake for growth and reproduction (as shown by the distribution of sample points in Figure 14).

The most interesting finding is the change of $\mathrm{COD}_{\mathrm{Mn}}$. The $\mathrm{COD}_{\mathrm{Mn}}$ in 2006-2015 had a weak negative effect on the growth and reproduction of algal blooms, but the effect was influentially positive in 2016-2018, which differs from the previous studies, in which $\mathrm{COD}_{\mathrm{Mn}}$ always had a positive effect on algal blooms [5,45].

\subsection{Human Activities}

Most studies have reported that in addition to water quality and meteorological factors, human activities, which are the main cause of water pollution [3], affect the occurrence of algal blooms [10,54]. With the increase in population and the rapid growth of local economies, the nutritional load of lake basins has increased significantly since the end of the 20th century, thereby transforming oligotrophic lakes into eutrophic lakes [54]. Excessive use of fertilizers, increased fertilizer production, industrial waste, and domestic sewage are causes of excessive nutrient concentrations in lakes $[3,81]$.

As shown in Figure 20, the TPop of Kunming City increased from 4.809 million in 2000 to 6.783 million in 2017 (growth rate of 41\%). And the GDP increased from 62.63 billion yuan ( 8.89 billion US dollars) in 2000 to 485.76 billion yuan (68.99 billion US dollars) in 2017 (a nearly eightfold increase). Due to the rapid expansion of population and significantly growing economy, the total discharge of industrial wastewater and domestic sewage in urban areas increased from 209.39 million tons in 2000 to 861.97 million tons in 2017, thereby increasing the number of pollutants and nutrients in Lake Dianchi and creating conditions for the growth of algal blooms. As we can see, the MaxABs in every year has a positive correlation with TW. The relationship between the MaxABs peak value of 2002 and TW are not significant, which may be related to the climate of the year. There are significant differences between MaxABs and TW during 2010-2015, which may benefit from the large-scale planting of Eichhornia crassipes in the north of Lake Dianchi [39].

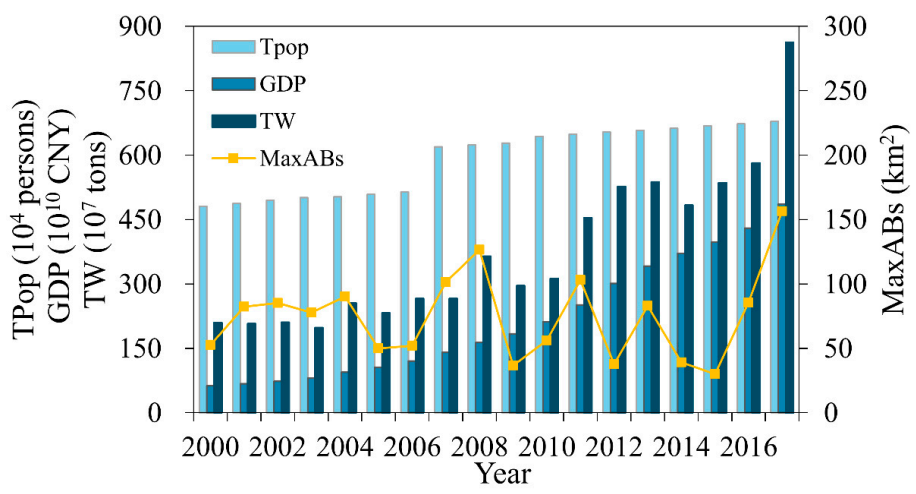

Figure 20. Total population, GDP, and total wastewater discharge in Kunming during 2000-2017. 


\section{Conclusions}

MODIS images have moderate spatial resolution and very high temporal resolution, providing a data basis for the dynamic monitoring of algal blooms in long time series. The APA, which has been proved to have higher accuracy than FAI, is capable of better identifying algal blooms on medium resolution remote sensing images.

The algal blooms in Lake Dianchi were influenced by the combination of meteorological and water quality factors, which were suitable for the growth and accumulation of algae. So they were observed all year round, with a reduced frequency in winter-spring and an increased frequency in summer-autumn, which lasted a long time for about 310-350 days. The severe algal blooms usually occurred in July-September every year. This is closely related to the increase in temperature and decrease in WS. From long time series, the top three largest areas of algal blooms were observed in 2002 , 2008, and 2017, reaching $168.80 \mathrm{~km}^{2}, 126.51 \mathrm{~km}^{2}$, and $156.34 \mathrm{~km}^{2}$, respectively. And the frequency and area of algal blooms have increased significantly in the past three years, which is likely to be influenced by the increase of DO. Besides, the discharge of wastewater has some promotion effect on the occurrence of algal blooms.

However, APA used in this research are based on $645 \mathrm{~nm}, 859 \mathrm{~nm}$, and $1240 \mathrm{~nm}$ on MODIS images, which has advantages in monitoring algae in general. For the lakes with the majority of cyanobacteria just like Lake Dianchi, we can try to improve the algorithm using the characteristic peak at $620 \mathrm{~nm}$ (such as OLCI/Sentinel 3) of phycocyanin to specifically extract cyanobacteria, which can further improve the extraction precision. Additional, different regions of the lake show substantial variations, and the average value of the entire lake is not completely representative of these regions. In addition to the factors analyzed in this study, food web structures, trophic interactions, and physicochemical environmental factors may affect the outbreak and distribution of algal blooms $[23,26,74]$. Therefore, it is necessary to further divide Lake Dianchi according to the outbreak degree of algal blooms [24] and then quantitatively study the relationship between the factors in each zone and their influence on algal blooms with in situ data. Only by accurately identifying the environmental driving forces of algae growth in Lake Dianchi can we further effectively monitor and prevent the occurrence of algae.

Author Contributions: Conceptualization, Y.Z.; Data curation, Y.J. and Q.C.; Formal analysis, Y.J. and Y.Z.; Funding acquisition, R.M.; Investigation, Y.J.; Methodology, Y.J. and Y.Z.; Project administration, Y.Z.; Resources, Y.Z. and M.H.; Software, Y.J., Y.Z. and M.H.; Supervision, Y.Z.; Validation, Y.J. and Y.Z.; Visualization, Y.J.; Writing —original draft, Y.J.; Writing—review \& editing, Y.Z.

Funding: This research was funded by the National Natural Science Foundation of China (Grant No. 41671371), Key Program of the National Natural Science Foundation of China (Grant No. 41431176), and National Key Technology Research and Development Program of the Ministry of Science and Technology of China during the "12th Five-Year Plan" (Grant No. 2015BAD13B06).

Acknowledgments: Acknowledgement for the data support from “Lake-Watershed Science Data Center, National Earth System Science Data Sharing Infrastructure, National Science \& Technology Infrastructure of China. (http://lake.geodata.cn)".

Conflicts of Interest: The authors declare no conflict of interest.

\section{References}

1. Wu, Z.; Liu, Y.; Liang, Z.; Wu, S.; Guo, H. Internal cycling, not external loading, decides the nutrient limitation in eutrophic lake: A dynamic model with temporal Bayesian hierarchical inference. Water Res. 2017, 116, 231-240. [CrossRef] [PubMed]

2. Pan, M.; Gao, L. Influence of socio-economic development of Dianchi Lake Basin on water quality change of Dianchi Lake. Chin. Eng. Sci. 2010, 12, 117-122.

3. Li, X.; Janssen, A.B.G.; de Klein, J.J.M.; Kroeze, C.; Strokal, M.; Ma, L.; Zheng, Y. Modeling nutrients in Lake Dianchi (China) and its watershed. Agric. Water Manag. 2019, 212, 48-59. [CrossRef]

4. Zhang, T.; Zeng, W.H.; Wang, S.R.; Ni, Z.K. Temporal and spatial changes of water quality and management strategies of Dianchi Lake in southwest China. Hydrol. Earth Syst. Sci. Discuss. 2013, 10, 15409-15432. [CrossRef] 
5. Wang, J.H.; Yang, C.; He, L.Q.; Dao, G.H.; Du, J.S.; Han, Y.P.; Wu, G.X.; Wu, Q.Y.; Hu, H.Y. Meteorological factors and water quality changes of Plateau Lake Dianchi in China (1990-2015) and their joint influences on cyanobacterial blooms. Sci. Total Environ. 2019, 665, 406-418. [CrossRef]

6. Liu, Y.; Li, Y.; Yang, X.; Zhang, J.; Guan, J.; Wang, J.; Zhang, H.; Xu, C. Analysis of pollution in Dianchi Lake and consideration of its application in crop planting. Procedia Environ. Sci. 2012, 12, 174-183. [CrossRef]

7. Li, Z.; Zheng, Y.; Zhang, D. Impacts of 20-year socio-economic development on aquatic environment of Lake Dianchi Basin. J. Lake Sci. 2012, 24, 875-882.

8. Paerl, H.W.; Ustach, J.F. Blue-green algal scums: An explanation for their occurrence during freshwater blooms. Limnol. Oceanogr. 1982, 27, 212-217. [CrossRef]

9. Li, Y.; Zhang, M.; Wang, R. The temporal and spation variation of the cyanobacteria which caused the water bloom in the Dianchi Lake, Kunming, China. J. Yunnan Univ. 2005, 27, 272-276.

10. Huang, C.; Wang, X.; Yang, H.; Li, Y.; Wang, Y.; Chen, X.; Xu, L. Satellite data regarding the eutrophication response to human activities in the plateau lake Dianchi in China from 1974 to 2009. Sci. Total Environ. 2014, 485-486, 1-11. [CrossRef]

11. Merel, S.; Walker, D.; Chicana, R.; Snyder, S.; Baures, E.; Thomas, O. State of knowledge and concerns on cyanobacterial blooms and cyanotoxins. Environ. Int. 2013, 59, 303-327. [CrossRef] [PubMed]

12. Yu, G.; Jiang, Y.; Song, G.; Tan, W.; Zhu, M.; Li, R. Variation of Microcystis and microcystins coupling nitrogen and phosphorus nutrients in Lake Erhai, a drinking-water source in Southwest Plateau, China. Environ. Sci. Pollut. Res. Int. 2014, 21, 9887-9898. [CrossRef] [PubMed]

13. Jiang, D. Spatio-Temporal Variation and Driving Factor Analysis of Algae Blooms in Dianchi Lake Based on GIS/RS. Master's Thesis, Southwest University, Chongqing, China, 2015.

14. Brooks, B.W.; Lazorchak, J.M.; Howard, M.D.; Johnson, M.V.; Morton, S.L.; Perkins, D.A.; Reavie, E.D.; Scott, G.I.; Smith, S.A.; Steevens, J.A. Are harmful algal blooms becoming the greatest inland water quality threat to public health and aquatic ecosystems? Environ. Toxicol. Chem. 2016, 35, 6-13. [CrossRef] [PubMed]

15. Li, H.; Hou, G.; Dakui, F.; Xiao, B.; Song, L.; Liu, Y. Prediction and elucidation of the population dynamics of Microcystis spp. in Lake Dianchi (China) by means of artificial neural networks. Ecol. Inform. 2007, 2, 184-192. [CrossRef]

16. Christiansen, G.; Fastner, J.; Erhard, M.; Borner, T.; Dittmann, E. Microcystin biosynthesis in Planktothrix: Genes, evolution, and manipulation. J. Bacteriol. 2003, 185, 564-572. [CrossRef]

17. Wu, Y.; Li, L.; Gan, N.; Zheng, L.; Ma, H.; Shan, K.; Liu, J.; Xiao, B.; Song, L. Seasonal dynamics of water bloom-forming Microcystis morphospecies and the associated extracellular microcystin concentrations in large, shallow, eutrophic Dianchi Lake. J. Environ. Sci. 2014, 26, 1921-1929. [CrossRef]

18. Ma, H.; Wu, Y.; Gan, N.; Zheng, L.; Li, T.; Song, L. Growth inhibitory effect of Microcystis on Aphanizomenon flos-aquae isolated from cyanobacteria bloom in Lake Dianchi, China. Harmful Algae 2015, 42, 43-51. [CrossRef]

19. Wang, S.; Zhu, L.; Li, Q.; Li, G.; Li, L.; Song, L.; Gan, N. Distribution and population dynamics of potential anatoxin-a-producing cyanobacteria in Lake Dianchi, China. Harmful Algae 2015, 48, 63-68. [CrossRef]

20. Cirés, S.; Wörmer, L.; Timón, J.; Wiedner, C.; Quesada, A. Cylindrospermopsin production and release by the potentially invasive cyanobacterium Aphanizomenon ovalisporum under temperature and light gradients. Harmful Algae 2011, 10, 668-675. [CrossRef]

21. Zhao, C.S.; Shao, N.F.; Yang, S.T.; Ren, H.; Ge, Y.R.; Zhang, Z.S.; Feng, P.; Liu, W.L. Quantitative assessment of the effects of human activities on phytoplankton communities in lakes and reservoirs. Sci. Total Environ. 2019, 665, 213-225. [CrossRef]

22. Wang, J.; He, L.; Yang, C.; Dao, G.; Du, J.; Han, Y.; Wu, G.; Wu, Q.; Hu, H. Comparison of algal bloom related meteorological and water quality factors and algal bloom conditions among Lakes Taihu, Chaohu, and Dianchi (1981-2015). J. Lake Sci. 2018, 30, 897-906.

23. Shan, K.; Li, L.; Wang, X.; Wu, Y.; Hu, L.; Yu, G.; Song, L. Modelling ecosystem structure and trophic interactions in a typical cyanobacterial bloom-dominated shallow Lake Dianchi, China. Ecol. Model. 2014, 291, 82-95. [CrossRef]

24. Li, G.; Li, L.; Pan, M.; Xie, Z.; Li, Z.; Xiao, B.; Liu, G.; Chen, J.; Song, L. The degradation cause and pattern characteristics of Lake Dianchi ecosystem and new restoration of ecoregion and step-by-step implementation. J. Lake Sci. 2014, 26, 485-496. 
25. Liu, Y.; Wang, Z.; Guo, H.; Yu, S.; Sheng, H. Modelling the effect of weather conditions on cyanobacterial bloom outbreaks in Lake Dianchi: A rough decision-adjusted logistic regression model. Environ. Model. Assess. 2013, 18, 199-207. [CrossRef]

26. Sheng, H.; Liu, H.; Wang, C.; Guo, H.; Liu, Y.; Yang, Y. Analysis of cyanobacteria bloom in the Waihai part of Dianchi Lake, China. Ecol. Inform. 2012, 10, 37-48. [CrossRef]

27. Zhou, Q.; Zhang, Y.; Lin, D.; Shan, K.; Luo, Y.; Zhao, L.; Tan, Z.; Song, L. The relationships of meteorological factors and nutrient levels with phytoplankton biomass in a shallow eutrophic lake dominated by cyanobacteria, Lake Dianchi from 1991 to 2013. Environ. Sci. Pollut. Res. Int. 2016, 23, 15616-15626. [CrossRef]

28. Cao, X.; Wang, Y.; He, J.; Luo, X.; Zheng, Z. Phosphorus mobility among sediments, water and cyanobacteria enhanced by cyanobacteria blooms in eutrophic Lake Dianchi. Environ. Pollut. 2016, 219, 580-587. [CrossRef]

29. Shi, K.; Zhang, Y.; Zhang, Y.; Li, N.; Qin, B.; Zhu, G.; Zhou, Y. Phenology of phytoplankton blooms in a trophic lake observed from long-term MODIS data. Environ. Sci. Technol. 2019, 53, 2324-2331. [CrossRef]

30. Hu, M.; Zhang, Y.; Ma, R.; Zhang, Y. Spatial and temporal dynamics of floating algal blooms in Lake Chaohu in 2016 and their environmental drivers. Environ. Sci. 2018, 39, 4925-4937.

31. Tao, M.; Duan, H.; Cao, Z.; Loiselle, S.; Ma, R. A hybrid EOF algorithm to improve MODIS cyanobacteria phycocyanin data quality in a highly Turbid lake: Bloom and nonbloom condition. IEEE J. Sel. Top. Appl. Earth Obs. Remote Sens. 2017, 10, 4430-4444. [CrossRef]

32. Shi, K.; Zhang, Y.; Zhou, Y.; Liu, X.; Zhu, G.; Qin, B.; Gao, G. Long-term MODIS observations of cyanobacterial dynamics in Lake Taihu: Responses to nutrient enrichment and meteorological factors. Sci. Rep. 2017, 7, 40326. [CrossRef] [PubMed]

33. Liang, Q.; Zhang, Y.; Ma, R.; Loiselle, S.; Li, J.; Hu, M. A MODIS-based novel method to distinguish surface cyanobacterial scums and aquatic macrophytes in Lake Taihu. Remote Sens. 2017, 9, 133. [CrossRef]

34. Li, J.; Zhang, Y.; Ma, R.; Duan, H.; Loiselle, S.; Xue, K.; Liang, Q. Satellite-based estimation of column-integrated algal biomass in nonalgae bloom conditions: A case study of Lake Chaohu, China. IEEE J. Sel. Top. Appl. Earth Obs. Remote Sens. 2017, 10, 450-462. [CrossRef]

35. Zhang, J.; Chen, L.; Chen, X. Monitoring the cyanobacterial blooms on remote sensing in Lake Erhai by FAI. J. Lake Sci. 2016, 28, 718-725.

36. Woźniak, M.; Bradtke, K.; Darecki, M.; Krężel, A. Empirical model for phycocyanin concentration estimation as an indicator of cyanobacterial bloom in the optically complex coastal waters of the Baltic Sea. Remote Sens. 2016, 8, 212. [CrossRef]

37. Lu, W.; Yu, L.; Ou, X.; Li, F. Relationship between occurrence frequency of cyanobacteria bloom and meteorological factors in Lake Dianchi. J. Lake Sci. 2017, 29, 534-545.

38. Zhu, L. Remote sensing monitoring and annual statistical analysis of blue algae bloom in Dianchi Lake based on HJ-1CCD. In Proceedings of the 16th China Forum on Environmental Remote Sensing Application Technology, Nanning, China, 28 March-1 April 2012; p. 7.

39. Zhao, D.; Li, J.; Hu, R.; Shen, Q.; Zhang, F. Landsat-satellite-based analysis of spatial-temporal dynamics and drivers of CyanoHABs in the plateau Lake Dianchi. Int. J. Remote Sens. 2018, 39, 8552-8571. [CrossRef]

40. Hu, C. A novel ocean color index to detect floating algae in the global oceans. Remote Sens. Environ. 2009, 113, 2118-2129. [CrossRef]

41. Hu, C.; Lee, Z.; Ma, R.; Yu, K.; Li, D.; Shang, S. Moderate resolution imaging spectroradiometer (MODIS) observations of cyanobacteria blooms in Taihu Lake, China. J. Geophys. Res. 2010, 115, C04002. [CrossRef]

42. Oyama, Y.; Fukushima, T.; Matsushita, B.; Matsuzaki, H.; Kamiya, K.; Kobinata, H. Monitoring levels of cyanobacterial blooms using the visual cyanobacteria index (VCI) and floating algae index (FAI). Int. J. Appl. Earth Obs. Geoinf. 2015, 38, 335-348. [CrossRef]

43. Tang, X.; Shen, M.; Duan, H. Temporal and spatial distribution of algal blooms in Lake Chaohu, 2000-2015. J. Lake Sci. 2017, 29, 276-284.

44. Zhang, Y.; Ma, R.; Duan, H.; Loiselle, S.A.; Xu, J.; Ma, M. A novel algorithm to estimate algal bloom coverage to subpixel resolution in Lake Taihu. IEEE J. Sel. Top. Appl. Earth Obs. Remote Sens. 2014, 7, 3060-3068. [CrossRef]

45. Zhang, Y.; Ma, R.; Duan, H.; Loiselle, S.; Xu, J. Satellite analysis to identify changes and drivers of CyanoHABs dynamics in Lake Taihu. Water Sci. Technol. Water Supply 2016, 16, 1451-1466. [CrossRef] 
46. Zhang, Y.; Ma, R.; Zhang, M.; Duan, H.; Loiselle, S.; Xu, J. Fourteen-year record (2000-2013) of the spatial and temporal dynamics of floating algae blooms in Lake Chaohu, observed from time series of MODIS images. Remote Sens. 2015, 7, 10523-10542. [CrossRef]

47. Gao, W.; Howarth, R.W.; Swaney, D.P.; Hong, B.; Guo, H.C. Enhanced N input to Lake Dianchi Basin from 1980 to 2010: Drivers and consequences. Sci. Total Environ. 2015, 505, 376-384. [CrossRef]

48. Gong, A.; Song, T.; Lin, Z. Cause of concrete carbonization erosion in Xiyuan Tunnel, Dianchi. Sci. Water Resour. 2007, 25, 110-112.

49. Vermote, E.F.; Tanré, D.; Deuze, J.L.; Herman, M.; Morcette, J.J. Second simulation of the satellite signal in the solar spectrum, 6S: An overview. IEEE Trans. Geosci. Remote Sens. 1997, 35, 675-686. [CrossRef]

50. Torbick, N.; Ziniti, B.; Stommel, E.; Linder, E.; Andrew, A.; Caller, T.; Haney, J.; Bradley, W.; Henegan, P.L.; Xun, S. Assessing cyanobacterial harmful algal blooms as risk factors for amyotrophic lateral sclerosis. Neurotox. Res. 2017, 33, 227. [CrossRef]

51. Chun, Y.; Ko, Y.G.; Do, T.; Jung, Y.; Kim, S.W.; Chun, Y.J.; Choi, U.S. Electrorheological properties of algae dispersed suspension: New application of harmful algae. Colloids Surf. A 2018, 539, 354-363. [CrossRef]

52. Knutson, C.M.; McLaughlin, E.M.; Barney, B.M. Effect of temperature control on green algae grown under continuous culture. Algal Res. 2018, 35, 301-308. [CrossRef]

53. Wang, S.; Gao, Y.; Li, Q.; Gao, J.; Zhai, S.; Zhou, Y.; Cheng, Y. Long-term and inter-monthly dynamics of aquatic vegetation and its relation with environmental factors in Taihu Lake, China. Sci. Total Environ. 2019, 651, 367-380. [CrossRef] [PubMed]

54. Guo, W.; Yang, F.; Li, Y.; Wang, S. New insights into the source of decadal increase in chemical oxygen demand associated with dissolved organic carbon in Dianchi Lake. Sci. Total Environ. 2017, 603-604, 699-708. [CrossRef] [PubMed]

55. Liu, J.; Yang, Y.; Gao, J.; Jiang, J. Characteristics of cyanobacteria bloom grading and its temporal and spatial variation in Taihu Lake. Resour. Environ. Yangtze Basin 2011, 20, 156-160.

56. He, Y.; Xiong, Q.; Luo, X.; Li, T.; Yu, L. Study on spatio-temporal changes of water bloom in Dianchi Lake based on NDVI. Ecol. Environ. Sci. 2019, 28, 555-563.

57. Li, X.; Zhao, K.; Cong, G.; Jensen, C.S.; Wei, W. Deep representation learning for trajectory similarity computation. In Proceedings of the 2018 IEEE 34th International Conference on Data Engineering (ICDE), Paris, France, 16-19 April 2018.

58. Gad, M.A.; Elshehaly, M.H.; Gračanin, D.; Elmongui, H.G. A tracking analyst for large 3D spatiotemporal data from multiple sources (case study: Tracking volcanic eruptions in the atmosphere). Comput. Geosci. 2018, 111, 283-293. [CrossRef]

59. Yang, Y.; Chen, J.; Tong, T.; Li, B.; He, T.; Liu, Y.; Xie, S. Eutrophication influences methanotrophic activity, abundance and community structure in freshwater lakes. Sci. Total Environ. 2019, 662, 863-872. [CrossRef]

60. Shan, K.; Song, L.; Chen, W.; Li, L.; Liu, L.; Wu, Y.; Jia, Y.; Zhou, Q.; Peng, L. Analysis of environmental drivers influencing interspecific variations and associations among bloom-forming cyanobacteria in large, shallow eutrophic lakes. Harmful Algae 2019, 84, 84-94. [CrossRef]

61. Yang, K.; Yu, Z.; Luo, Y.; Yang, Y.; Zhao, L.; Zhou, X. Spatial and temporal variations in the relationship between lake water surface temperatures and water quality-A case study of Dianchi Lake. Sci. Total Environ. 2018, 624, 859-871. [CrossRef]

62. Kong, F.; Gao, G. Hypothesis on cyanobacteria bloom-forming mechanism in large shallow eutrophic lakes. Acta Ecol. Sin. 2005, 25, 589-595.

63. Zhou, Q.; Chen, W.; Shan, K.; Zheng, L.; Song, L. Influence of sunlight on the proliferation of cyanobacterial blooms and its potential applications in Lake Taihu, China. J. Environ. Sci. 2014, 26, 626-635. [CrossRef]

64. Bormans, M.; Sherman, B.S.; Webster, I.T. Is buoyancy regulation in cyanobacteria an adaptation to exploit separation of light and nutrients? Mar. Freshw. Res. 1999, 50, 897-906. [CrossRef]

65. Xiao, Y.; Gan, N.; Liu, J.; Zheng, L.; Song, L. Heterogeneity of buoyancy in response to light between two buoyant types of cyanobacterium Microcystis. Hydrobiologia 2011, 679, 297-311. [CrossRef]

66. Wu, T.; Qin, B.; Zhu, G.; Luo, L.; Ding, Y.; Bian, G. Dynamics of cyanobacterial bloom formation during short-term hydrodynamic fluctuation in a large shallow, eutrophic, and wind-exposed Lake Taihu, China. Environ. Sci. Pollut. Res. Int. 2013, 20, 8546-8556. [CrossRef] [PubMed] 
67. Qin, B.; Li, W.; Zhu, G.; Zhang, Y.; Wu, T.; Gao, G. Cyanobacterial bloom management through integrated monitoring and forecasting in large shallow eutrophic Lake Taihu (China). J. Hazard. Mater. 2015, 287, 356-363. [CrossRef] [PubMed]

68. Bresciani, M.; Adamo, M.; Carolis, G.D.; Matta, E.; Pasquariello, G.; Vaičiūtè, D.; Giardino, C. Monitoring blooms and surface accumulation of cyanobacteria in the Curonian Lagoon by combining MERIS and ASAR data. Remote Sens. Environ. 2014, 146, 124-135. [CrossRef]

69. Zhang, M.; Duan, H.; Shi, X.; Yu, Y.; Kong, F. Contributions of meteorology to the phenology of cyanobacterial blooms: Implications for future climate change. Water Res. 2012, 46, 442-452. [CrossRef] [PubMed]

70. Wang, W.; Li, Y.; Xu, X.; Du, W.; Wu, X. Study on spatial distribution characteristics of nutrients in Dianchi Lake in summer. Water Resour. Power 2016, 34, 36-39.

71. Zhang, M.; Zhang, Y.; Yang, Z.; Wei, L.; Yang, W.; Chen, C.; Kong, F. Spatial and seasonal shifts in bloom-forming cyanobacteria in Lake Chaohu: Patterns and driving factors. Phycol. Res. 2016, 64, 44-55. [CrossRef]

72. Kosten, S.; Huszar, V.L.M.; Bécares, E.; Costa, L.S.; Donk, E.; Hansson, L.-A.; Jeppesen, E.; Kruk, C.; Lacerot, G.; Mazzeo, N.; et al. Warmer climates boost cyanobacterial dominance in shallow lakes. Glob. Chang. Biol. 2012, 18, 118-126. [CrossRef]

73. An, K.-G.; Jones, J.R. Factors regulating bluegreen dominance in a reservoir directly influenced by the Asian monsoon. Hydrobiologia 2000, 432, 37-48. [CrossRef]

74. Liu, Z.; Liu, X.; He, B.; Nie, J.; Peng, J.; Zhao, L. Spatio-temporal change of water chemical elements in Lake Dianchi, China. Water Environ. J. 2009, 23, 235-244. [CrossRef]

75. Ibelings, B.W.; Bormans, M.; Fastner, J.; Visser, P.M. CYANOCOST special issue on cyanobacterial blooms: Synopsis-A critical review of the management options for their prevention, control and mitigation. Aquat. Ecol. 2016, 50, 595-605. [CrossRef]

76. Paerl, H.W.; Otten, T.G. Harmful cyanobacterial blooms: Causes, consequences, and controls. Microb. Ecol. 2013, 65, 995-1010. [CrossRef] [PubMed]

77. Sun, J.; Cao, X.; Huang, Y. Relationships between spatial-temporal trends of water quality and the human activities in Lake Dianchi. J. Lake Sci. 2012, 24, 347-354.

78. Reichwaldt, E.S.; Ghadouani, A. Effects of rainfall patterns on toxic cyanobacterial blooms in a changing climate: Between simplistic scenarios and complex dynamics. Water Res. 2012, 46, 1372-1393. [CrossRef]

79. Zhang, C.; Lai, S.; Gao, X.; Liu, H. A review of the potential impacts of climate change on water environment in lakes and reservoirs. J. Lake Sci. 2016, 28, 691-700.

80. Hai, X.U.; Paerl, H.W.; Qin, B.; Zhu, G.; Gao, G. Nitrogen and phosphorus inputs control phytoplankton growth in eutrophic Lake Taihu, China. Limnol. Oceanogr. 2010, 55, 420-432.

81. Zhou, J.; Liu, Y.; Guo, H.; He, D. Combining the SWAT model with sequential uncertainty fitting algorithm for streamflow prediction and uncertainty analysis for the Lake Dianchi Basin, China. Hydrol. Process. 2014, 28, 521-533. [CrossRef]

(C) 2019 by the authors. Licensee MDPI, Basel, Switzerland. This article is an open access article distributed under the terms and conditions of the Creative Commons Attribution (CC BY) license (http://creativecommons.org/licenses/by/4.0/). 